\title{
How Does This Monument Make You Feel? Measuring Emotional Responses to War Memorials in Croatia
}

\author{
Vjeran Pavlaković and Benedikt Perak
}

Since the collapse of communism and the disintegration of Yugoslavia, collective remembrance in all of the successor states has undergone dramatic transformations as part of nation-building projects and strategies to bolster the legitimacy of new political elites. This has included nationalist revisionism of the narratives of the Second World War and the creation of founding myths based on the bloody wars accompanying Yugoslavia's dissolution. Although there is a general agreement across the political spectrum regarding the dominant nation-building narrative in Croatia, which emphasizes its victory in the War of Independence (known as the Domovinski rat, or Homeland War, 1991-1995), there is considerably less consensus over the Second World War. ${ }^{1}$ This so-called 'red-black ideological division' in society is manifested in seemingly perpetual politicized debates over communist Partisans, fascist Ustaša, and Serb extremist Četniks, which is then additionally distorted by the more recent traumas of the 1990s conflict. The need for unity during the Homeland War led to the policy of 'national reconciliation' under the first Croatian president, Franjo Tuđman, which emphasized the struggle for statehood as one of the goals of the Croatian Partisans and concurrently whitewashed the Ustaša movement of its fascist ideology. The long-term consequences were the demonization of the antifascist struggle and the rehabilitation of Nazifascist collaborators, which was played out across the country's memoryscape: thousands of Partisan memorials have been damaged or completely destroyed

1 The results of the research project "Symbolic Strategies of Nation-building in the Western Balkans," which included a detailed opinion poll that posed questions about both the Second World War and the Homeland War, showed that the majority of respondents in Croatia held the official narrative of the latter to reflect the truth, while interpretations of the former were considerably polarized. The complete results of the opinion poll are available at http:// cultstud.ffri.hr/istrazivanje/projekti/118-symbolic-strategies. See also Vjeran Pavlaković, "Fulfilling the Thousand-Year-Old Dream: Strategies of Symbolic Nation-building in Croatia", in Pål Kolstø, ed., Strategies of Symbolic Nation-building in South Eastern Europe (Farnham: Ashgate, 2014).

(C) VJERAN PAVLAKOVIĆ AND BENEDIKT PERAK, 2017 | DOI 10.1163/9789004352353_013 
since 1991, while new monuments and public spaces have been dedicated to some of Hitler's most fervent allies. The victorious and emancipatory narrative of antifascism has slowly been replaced with an anti-communist victimization discourse perpetuated through commemorative practices at various sites of memory.

Croatia's efforts to join the European Union has meant that since 2000, its administrations have had to adopt the transnational narratives of antifascist founding myths, resulting in the partial revalorization of the Partisan struggle. Right-wing political parties have also adopted the Eu discourse on the Second World War, although by condemning communist crimes, and they have sought to equate all totalitarian systems through EU memorial days such as the Day of Remembrance for Victims of all Authoritarian and Totalitarian Regimes (23 August). After Croatia was admitted to the EU on 1 July 2013, many political observers and scholars predicted that the bitter polemics over the Second World War would play a minor role compared to the burning socio-economic issues plaguing the country. However, since the EU accession, symbolic politics centred on interpretations of the Second World War, as well as renewed debates on the Homeland War, have continued to dominate headlines and divide the political elites at a time when a unified strategy for resolving the economic crisis has been most needed. The election of a short-lived right-wing coalition in 2016 exacerbated the red-black division, particularly over cultural policies, memory politics and commemorative practices.

Previous research presented at conferences related to COST action IS1203 (In search of transnational memory in Europe) has traced the top-down strategies of rehabilitating the Ustaša in post-1990 Croatia, transnational EU discourse in Croatian memory politics and collective remembrance of communism. ${ }^{2}$ The challenge, however, is how to measure the reception of these various stages of reframing the past. As a part of the project 'Framing the Nation and Collective Identity in Croatia: Cultural Memory of 2oth Century Traumas, ${ }^{3}$ this chapter seeks to analyze to what degree perceptions of past

2 "Remembering War the European Way: Croatia's Commemorative Culture and the EU", EU Politics of Memory Conference, European University Institute, Florence, Italy (20 June 2015); "EU Narratives and the Specter of Communism in Croatia," cost Conference - Memory of Communism in Europe, Paris, France (15-16 May 2014); and "Creating Victims out of Perpetrators: Symbolic Strategies of Rehabilitating World War Two Collaborators in Croatia since the 199os," cost meeting Social Construction of Guilt and Victimhood, Krakow, Poland (16 September 2013).

3 This project is funded by the Croatian Science Foundation (HRzz - Hrvatska zaklada za znanost). 
wars are shaped by commemorative practices, monuments, political speeches and media representations of political rituals. Drawing upon the material gathered at several commemorations (including video footage of speeches, photographs of monuments and media coverage), our goal was to develop a survey to measure emotional responses to a controversial Second World War memorial in Croatia. We wanted to measure firstly the reaction to a decontextualized visual representationof the monument and secondly measure the response to the same representation but this time contextualized with various commemorative speeches imbuing the static monument with conceptualizations of meaning. The selected monument - along with a memorial complex, archive and museum - commemorates the notorious concentration camp of Jasenovac established by the Ustaša regime in the Independent State of Croatia (NDH - Nezavisna Država Hrvatska). An increasingly vocal group of right-wing historians, journalists and politicians has sought to erase, or at least radically redefine, the narratives associated with this site of memory by questioning the number of victims and rehabilitating the perpetrators. The memorial already underwent a transformation in meaning during the shift from socialist Yugoslavia to independent Croatia, and the latest efforts to undermine the accepted historical narrative are representedby an attempt to inscribe alternative meanings in line with right-wing interpretations of the Second World War. In the midst of this cacophony of state-promoted narratives and revisionist counternarratives bordering on conspiracy theories, is it possible to determine how Croatian society perceives this dark episode from the 2oth century?

One of the important questions in the research of the collective memory is the influence of the emotional and cognitive dimensions in the mechanism of social memory transmission. How successfully are the subjective qualities of the individual memories transmitted and elicited in the inter-subjective communication? What are the salient emotional and cognitive features of the narration that successfully construct a socially shared memory? Can we measure the level of affective and cognitive engagement of the receivers of the representations of the cultural memories prominent in social communication and media? Can we predict the behavioural and pragmatic tendencies based on the level of emotional and cognitive appraisal? Can we correlate the level of emotional and cognitive appraisal with the representation of a particular event in a collective memory? This chapter tackles some of the abovementioned questions by investigating the effects of a monument's representations, associated commemorative speeches, and media coverage on the individual's affective and cognitive stance about the traumatic events in Croatian collective memory. In order to formulate the reception of this multimodal representation we situate the present study on the collective memory within the theoretical 
framework of embodied cognition, ${ }^{4}$ cognitive linguistics approaches to the conceptualization of social identity, ${ }^{5}$ cultural linguistics notion of socially distributed cognition ${ }^{6}$ and componential appraisal theory of emotion. ${ }^{7}$

This theoretical framework implies that the construction of a commemorative event establishes socially distributed conceptualization networks that can involve several (conflicting) conceptualizing models. ${ }^{8}$ In other words, the same event can be construed differently by profiling different frames, resulting in specific emotional, cognitive and behavioural responses. The study presented in this article measures and compares the emotional and cognitive engagement of subjects when exposed to differently construed types of commemorative events. Its aim is to quantitatively compare the affective appraisal and cognitive responses of 'shallow conceptual' elicitation via a decontextualized static image of the monument (Figure 12.3), with the 'deep conceptual' elicitation of monument representation contextualized with the speeches delivered by the selected memory producing actors. The theoretical assumption is that the level of emotional and cognitive engagement produced by the visual conceptual elicitation via an image represents the established individual's stance to the constructed (mediated) collective memory. This 'shallow' categorical knowledge is seen as the activation of the salient conceptual patterns in the dynamic system of individual mental representation (knowledge) of the event. On the other hand, the conceptualized elicitation of the event, contextualized via political speeches, is seen as the 'deeper' framing of the individual's conceptual model. The contextualized representation engages

4 L. Barsalou, "Grounded Cognition," Annual Review of Psycholgy, (2008) 59. See also Benedikt Perak and Sanja Puljar D’Alessio, "Kultura kao emergentno svojstvo otjelovljene spoznaje," in Nenad Fanuko and Sanja Puljar D’Alessio (eds.), Avanture kulture: kulturalni studiji u lokalnom kontekstu (Zagreb: Jesenski and Turk, 2013), 77-108.

5 George Lakoff, Moral Politics: What Conservatives Know that Liberals Don't (Chicago: University of Chicago Press, 1996); George Lakoff, The Political Mind: A Cognitive Scientist's Guide to Your Brain and Its Politics (New York: Penguin Books, 2009).

6 Farzad Sharifian, "Cultural linguistics", in Farzad Sharifian, ed., The Routledge Handbook of Language and Culture (London: Routledge, 2015), 473-492; Roslyn M. Frank, "A future agenda for research on language and culture" in Sharifian, The Routledge Handbook of Language and Culture, $493-512$.

7 Klaus Scherer, 2009. "Emotions are emergent processes: they require a dynamic computational architecture," in Philosophical Transaction of the Royal Society, 364 (2009), 3459-34747; Johnny R.J. Fontaine, Klaus Scherer and Cristiana Soriano, eds., Components of emotional meaning: A sourcebook (Oxford: Oxford University Press, 2013).

8 Gabriel A. Radvansky and Jeffrey M. Zacks, Event Cognition (Oxford: Oxford University Press, 2014); George Lakoff, The political mind: A cognitive scientist's guide to your brain and its politics. (New York: Penguin, 2008). 
more processing of the affective and cognitive resources, and consequently is expected to produce a more elaborated affective appraisal and complex activation of entrenched conceptual networks for a given commemorative event. The difference in the affect response between these two types of elicitation is thus seen as an effect of the conceptualization strategies, involving change in affective stance and dynamic negotiation between individually entrenched cognitive models and socially conventionalized cultural models in the process of distributing cognition, (intergenerational) transmission, appropriation and remediation of the meaning in culture. By comparing the features of decontextualized and contextualized types of elicitation we formulated an instrument for the qualitative and quantitative description of the intersubjective dynamics of affect elicitation, cultural conceptualizations and incentives for norms of behaviour, as well as communication strategies that constitute an individual's relation to the collective identity.

In the first part of the chapter we present a historical background of the Second World War in Croatia, followed by an overview of memory politics in Croatia necessary for understanding post-socialist shifts in commemorative culture. Bleiburg, ${ }^{9} \mathrm{Srb}^{10}$ and Jasenovac represent some of the most controversial collective remembrance sites in post-1990 Croatia. The history of the Jasenovac Memorial site is thus presented along with the systematic revisionist strategies bordering on Holocaust denial pursued by various extreme Croatian nationalists in the media during 2015 and early 2016. In the second part

The commemorations in Bleiburg, located in Austria near the Slovenian border, symbolize the repression and mass killings of the defeated NDH forces, along with civilians, by the Partisans in the last phases of the Second World War and immediate post-war period. As in Jasenovac, the number of victims remains subject to manipulation and debate, and the commemoration itself has been controversial due to the rehabilitation of the NDH by many of the participants over the years. See Vjeran Pavlaković, "Deifying the Defeated: Commemorating Bleiburg since 1990," in L'Europe en Formation, No. 357 (December 2010). Formerly celebrated on 27 July as the Croatian Uprising Day during socialist Yugoslavia to honour the mass uprising in response to the Ustaša terror in 1941, the commemoration has been more of a local event organized by Croatian Serb organizations and Croatian antifascist associations since 2000. However, right-wing politicians and organizations claim the uprising was not antifascist but rather led by Četniks with the goal to ethnically cleanse the area of Croats. See Vjeran Pavlaković, "Contested Pasts, Contested Red-Letter Days: Antifascist Commemorations and Ethnic Identities in Post-Communist Croatia," in Ljiljana Šarić, Karen Gammelgaard and Kjetil Ra Hauge, eds., Transforming National Holidays: Identity Discourse in the West and South Slavic Countries, 1985-2010 (London: John Benjamins Publishing, 2012). 
of the article we present the methods, results and analyses of the affect and conceptualization response study related to Jasenovac. ${ }^{11}$

\section{The Second World War in Croatia and Memory Politics}

Although the Second World War radically transformed and affected all of the republics of former Yugoslavia, the traumas and deep divisions of that conflict can be felt particularly in contemporary Croatia due to the complex relationship between state-building narratives, legacies of both right- and left-wing extremist ideologies and interethnic violence perpetrated on a massive scale. The Homeland War in the 1990s reawakened many of the unresolved issues ofthe past, which had been suppressed for decades as part of the socialist regime's efforts to maintain its monopoly over the historical narrative. The ideology of 'brotherhood and unity' was coined to emphasize the unified struggle of all of Yugoslavia's peoples against the foreign occupiers and domestic collaborators, rather than to focus on the internecine slaughter of civilians and revenge killings. The cultural memory politics of socialist Yugoslavia (with some regional differences) have reflected this interpretation of the past in commemorative practices, monument construction, official historiographies and educational systems, as well as a broad range of cultural production until the system began unraveling in the 1980s, following Tito's death.

The Second World War on the territory of former Yugoslavia was not a clearcut struggle between foreign occupiers and a revolutionary guerrilla movement, but a multisided civil war characterized by the systematic persecution of rival ethnic and religious groups for over four violent years. ${ }^{12}$ The spiral of violence was particularly brutal in the $\mathrm{NDH}$, which included not only most of today's Croatia (notably lacking the Istrian Peninsula and most of the territory on the Adriatic coast), but also present-day Bosnia-Herzegovina. Members of the Ustaša terrorist movement established the NDH on 10 April 1941, just a few days following the Axis invasion and destruction of the Interwar-era Yugoslav

11 The Srb case study will be completed as part of the ongoing FRAMNAT research project.

12 See Marko Attila Hoare, Genocide and Resistance in Hitler's Bosnia: The Partisans and the Chetniks, 1941-1943 (Oxford: Oxford University Press, 2006); Vjeran Pavlaković, "Yugoslavia," in Phillip Cooke and Ben Shepherd, eds., European Resistance in the Second World War (Barnesly: Pen \& Sword Military, 2013); Stevan K. Pavlowitch, Hitler's New Disorder: The Second World War in Yugoslavia (London: Hurst \& Company, 2008); and Jozo Tomasevich, War and Revolution in Yugoslavia, 1941-1945: Occupation and Collaboration (Stanford: Stanford University Press, 2001). 
state (1918-1941). The Ustaša leader, Ante Pavelić, who had returned from his exile in Italy, quickly established a harsh dictatorship that passed racial laws against Serbs, Jews and Roma. The regime built a system of concentration camps (the most notorious being the Jasenovac complex) and violently repressed any opposition to his regime. While many Croats initially welcomed the NDH as salvation from the Serb-dominated Interwar Yugoslav state, the totalitarian methods of the Ustaša regime quickly revolted the majority of the population. Serbs, who comprised nearly $30 \%$ of the NDH's inhabitants, were the main targets of the regime's genocidal politics. They swelled the ranks of the growing Partisan resistance movement, organized by the Communist Party of Yugoslavia under Josip Broz Tito's command. Other Serbs joined the Četniks, who fought for the restoration of royal Yugoslavia, but engaged in numerous atrocities against Croat and Muslim civilians and eventually fully collaborated with the pro-Axis forces.

The Ustaše stayed loyal to Hitler until the end, and while much of the leadership, including Pavelić, were able to escape to the West after May 1945, tens of thousands of others associated (or allegedly associated) with the regime suffered in postwar communist massacres, death marches or other types of persecution, symbolically commemorated as the Bleiburg massacre and the Way of the Cross in May every year. ${ }^{13}$ Croats in particular were saddled with the guilt of the Ustaša crimes, even though by the end of the war hundreds of thousands of ethnic Croats had fought in the Partisan ranks. The legitimacy of the post-war socialist regime was based upon the official narratives of the Partisan struggle, referred to in the historiography as the People's Liberation Struggle (NOB - Narodnooslobodilčka borba). Although by the 1960 s Yugoslavia in many aspects was far more liberal than its neighbours in the Soviet bloc, the challenging of the state's interpretation of the past, especially the numbers of victims, was a taboo topic that could result in prison sentences. In addition to new rituals, commemorations, history books, films and cultural products which reinforced the Partisan narrative of the war, the communist regime erected thousands of monuments and memorials at important memory sites dedicated to the ideals of brotherhood and unity, socialist revolution, and sacrifice for the new Yugoslav state. ${ }^{14}$

13 Martina Grahek Ravančić, Bleiburg i križni put 1945.(Zagreb: Hrvatski institut za povijest, 2009).

14 Renata Jambrešić-Kirin, "Politička sjećanja na Drugi svjetski rat u doba medijske reprodukcije socijalističke culture," in Lada Čale Feldman and Ines Prica, eds., Devijacije $i$ promašaji: Etnografija domaćeg socijalizma (Zagreb: Institut za etnologiju i folkloristiku, 2006). 
After multiparty elections in 1990 and the rapid disintegration of communist ideology in Yugoslavia as well as Eastern Europe, the monopoly over the past crumbled along with the former political system. A proliferation of debates about the Second World War in Croatia contributed to the deterioration of Serb-Croat relations and the slide towards a new cycle of war. Slobodan Milošević, Serbia's president and architect of Yugoslavia's bloody dissolution, used his propaganda apparatus to spread fear among Croatia's Serbs of a renewed Ustaša threat. At the same time, Tuđman (himself a former Partisan officer) and his Croatian Democratic Union (HDZ - Hrvatski demokratski savez) tolerated the rehabilitation of the Ustaše in an attempt to bridge the red-black ideological divide among Croats. Despite the shameful policies during its brief existence and its inglorious end, the NDH remains romanticized in certain circles because of the predominance of the state-forming ideology (državotvornost) and ideas of 'state right' among nationalists. In their interpretation, the Ustaše had supposedly established the first independent state since the loss of national sovereignty in 1102, ignoring the fact that the NDH was divided and controlled by both Italy and Germany. Fetishization of the state led to the minimizing, and sometimes complete denial, of Ustaša crimes by émigrés who fled Tito's Yugoslavia, a trend that entered mainstream Croatian political culture after 1990. Nevertheless, the Croatian Constitution (adopted in December 1990 and amended most recently in 2010) cites the Partisan movement and zaVNoH (State Antifascist Council of the National Liberation of Croatia, the governing body of the Croatian Partisans) as part of the continuity of Croatian statehood..$^{15}$ The establishment of statehood (whether the NDH, the Socialist Republic of Croatia within a federal Yugoslavia, or independent Croatia in 1991) remains at the heart of war remembrance in Croatia. This includes speeches at sites such as Jasenovac - as described below - even though other commemorations are more relevant to the nation-building narrative.

Commemorations, along with other political rituals such as rallies, parades, anniversaries and other mass gatherings, are symbolic public activities that elites use to construct grand narratives of the national past and their own political legitimacy. 'Politics is expressed through symbolism,' asserts anthropologist David I. Kertzer, suggesting that even people in modern societies are more influenced by symbolic forms than rational calculations. ${ }^{16}$ While the majority of socialist-era monuments remained the same (those that werenot among the 3,000 damaged or destroyed ones), the content of the commemorative

\footnotetext{
15 Constitution of the Republic of Croatia, online version at http://www.zakon.hr/z/94/ Ustav-Republike-Hrvatske.

16 David I. Kertzer, Ritual, Politics, Power (New Haven: Yale University Press, 1988), 2.
} 
practices, especially the speeches, has inscribed new meanings into old sites. It is precisely the reception of what is inscribed into contested memory sites such as Jasenovac that our research is trying to analyze, two decades after the transition into multiparty democracy and the establishment of an independent nation-state.

\section{Jasenovac as a Controversial Site of Memory}

Along with the Bleiburg and Srb commemorations, the collective remembrance of Jasenovac is among the most controversial memory sites related to the Second World War in post-socialist Croatia. Unlike Bleiburg, where the small memorial is overshadowed by the chapel and outdoor altar hosting the commemorative speeches, Jasenovac is dominated by a massive monument that serves as a backdrop to the commemoration as well as an easily recognizable symbol frequently reproduced in the media (see Illustrations 2 and 3). The Jasenovac 'Flower', designed by architect Bogdan Bogdanović, represents the later trend of abstract memorial design known as Yugoslav socialist modernism. While many Partisan memorials, such as the Srb monument by sculptor Vanja Radauš, clearly depict scenes of the war in a socialist realist manner (heroic soldiers, grieving mothers, suffering civilians and murderous fascist enemies), Bogdanović's transcendent, almost alien monument does not in any way indicate that it marks the location of a brutal extermination camp. According to Bogdanović himself, "the "Flower" is an enigmatic construction. Just like the death of man is mysterious, especially in a shadowy time. The monument must be enigmatic.' ${ }^{17}$ This monument thus provides an interesting case study in trying to measure emotional reactions to a site of memory where the Yugoslav regime invested considerable resources in constructing a specific narrative of the past yet chose to do so through a memorial with ambiguous symbolism.

Unlike Auschwitz, Dachau or other former concentration camps, the Jasenovac Memorial Site lacks original buildings and is dominated by the massive concrete 'Flower' monument next to a memorial museum renovated in 2006. In contrast to the gas chambers of the Nazi death camps, victims in Jasenovac, the nearby Stara Gradiška and other Ustaša camps were often murdered

17 Interview with Bogdan Bogdanović quoted in Nataša Jovičić, "The Alchemy of the 'Flower"', in Tea Benčić Rimay, ed., Jasenovac Memorial Site, (Jasenovac: Spomen-područje Jasenovac, 2006), 229. 
through less systematic but more brutal methods. ${ }^{18}$ The estimated number of victims at Jasenovac has fluctuated wildly over the years and was subject to considerable political manipulation almost immediately after the end of the Second World War. The figure of 700,00o victims was considered sacrosanct in socialist-era Yugoslavia, and by the 1980 os some scholars inflated that number to allege that over 1 million individuals, predominantly Serbs, were killed in the camps alone. ${ }^{19}$ The reaction of Croatian nationalists, such as Franjo Tuđman, was to minimize the numbers. Even before he became president, Tuđman argued that the total death toll for all camps in Croatia was not more than 40,00o, a figure he continued to cite in the $1990 \mathrm{os}^{20}$ The museum's website currently lists just over 80,00o Serbs, Jews, Roma, Croats and individuals of other nationalities as victims, ${ }^{21}$ although scholars estimate that the final tally of victims is probably as high as $100,000 .{ }^{22}$ In her work on socialist Yugoslav monuments, historian Heike Karge has shown that the debates over the number of victims affected the decisions related to the building of a memorial at Jasenovac, including decisions at the highest political levels of the communist regime. ${ }^{23}$

As mentioned above, no original structures remain at the Jasenovac site. The Ustaše destroyed the camp and nearly all administrative records in 1945 when it became clear the war was lost, and in subsequent years the inhabitants of the town of Jasenovac scoured the ruins for building material to repair their devastated homes. In the 1950 os local officials floated the idea of creating some kind of memorial at the site, but it was not until 1963 that 1,500

18 Nataša Mataušić,Jasenovac 1941-1945 (Zagreb: Kameni cvijet, 2003); Mišo Deverić and Ivan Fumić, Hrvatska u logorima, 1941.-1945. (Zagreb: Savez antifašističkih boraca i antifašista Republike Hrvatske, 2008); and Slavko and Ivo Goldstein, Jasenovac i Bleiburg nisu isto (Zagreb: Novi liber, 2011).

19 Vladimir Žerjavić, Opsesije i megalomanije oko Jasenovca i Bleiburga (Zagreb: Globus, 1992), 11-12, 44; and Nataša Mataušić, "The Jasenovac Concentration Camp," in Rimay, ed., Jasenovac Memorial Site, 47-48.

Interview with Tuđman, reprinted in Novi list, 23 April 1996, 21. The discussion about the manipulation of the number of Jasenovac victims was featured in Franjo Tuđman's most well-known and controversial book, Bespuća povijesne zbiljnosti (1990). The notion of collective guilt was one of the central tenets of Tuđman's challenging the number of Serbian victims in the Second World War.

21 Tables identifying the victims at the Jasenovac camp by nationality can be found at www. jusp-jasenovac.hr/Default.aspx?sid=6711 (accessed 5 May 2016).

22 Archive of Javna ustanova Spomen područje (JUSP) Jasenovac, Fond SPJ - Komemoracije, A-745, Slakvo Goldstein, "Procjene o priližnom broju žrtava ustaškog logorskog sustava Jasenovac 1941-1945," 21 April 2005.

23 Heike Karge, Sećanje u kamenu - okamenjeno sećanje? Trans. Aleksandra Kostić (Belgrade: XX vek, 2014). 
people participated in a 'work action' to clear the terrain and that a decision was made to construct a monument. ${ }^{24}$ The Croatian People's Liberation War veterans' organization chose Belgrade architect Bogdan Bogdanovićs 'Flower' design (sometimes referred to as the 'Stone Flower,' Kameni cvijet, even though it is made from reinforced concrete), symbolizing 'indestructible life,' as the central monument. ${ }^{25}$ Work on the monument lasted from 1964 until the opening ceremony on $4 \mathrm{July} 1966 .{ }^{26} \mathrm{Gal} \mathrm{Kirn}$, a leading scholar on Yugoslav modernist monuments, explains that the abstract forms represent universalist values, timelessness and an antifascism that is not tied to a single nationalism. ${ }^{27}$ These memorials, even when located at the site of death camps such as Jasenovac, share the vision of modernization and education which Yugoslavia strove for but was ultimately unable to achieve due to its internal lack of cohesion. The construction ofa museum began in September 1967 and was completed in July 1968, the same year the Jasenovac Memorial Site Institution was established to administer the museum. In 1983 the Jasenovac Memorial Site was expanded to include all of the outlying camps that constituted the Jasenovac system, such as Krapje, Uštice, Stara Gradiška (the location of a women's camp) and Donja Gradina. The latter location is a massive killing field across the Sava River, an area which today belongs to Bosnia-Herzegovina (in the Republika Srpska entity). The once-united memorial site is therefore physically divided between two countries. The fragmentation of the memorial site has resulted in two radically different constructions of the past: the Croatian one, which offers a contemporary museum space and commemorative site, and a Bosnian Serb one which perpetuates the Jasenovac myths from the communist period.

In 1991 the memorial site was occupied by rebel Serb forces that devastated the museum and looted its collection. The objects ended up in a storage facility in Banja Luka (Bosnia-Herzegovina), were transferred to Washington, D.c.,

24 Duško Lončar, Deset godina spomen-područja Jasenovac (Jasenovac: Spomen-područje Jasenovac, 1977), 13-14.

25 Bogdanović stated in an interview that 'in the Jasenovac Flower I denoted life - the crimes which took place in Jasenovac were terrible, but it is important to show what comes afterwards.' Quoted in Jovičić, "The Alchemy of the 'Flower", 229.

26 Lončar, Deset godina spomen-područja Jasenovac, 13-14.

27 Gal Kirn, "A Few Critical Notes on the Destiny of the Yugoslav Partisan Memorial Sites in the Contemporary, Post-Yugoslav (Croatian) Context," in Nataša Ivančević, ed., Vojin Bakić: Lightbearing Forms - A Retrospective (Zagreb: Muzej suvremene umjetnosti, 2013), 288. See also Gal Kirn and Robert Burghardt, "Jugoslovenski partizanski spomenici: Između revolucionarne politike i apstraktnog modernizma," in Jugolink, vol. 2, no. 1 (2012), $7-20$. 


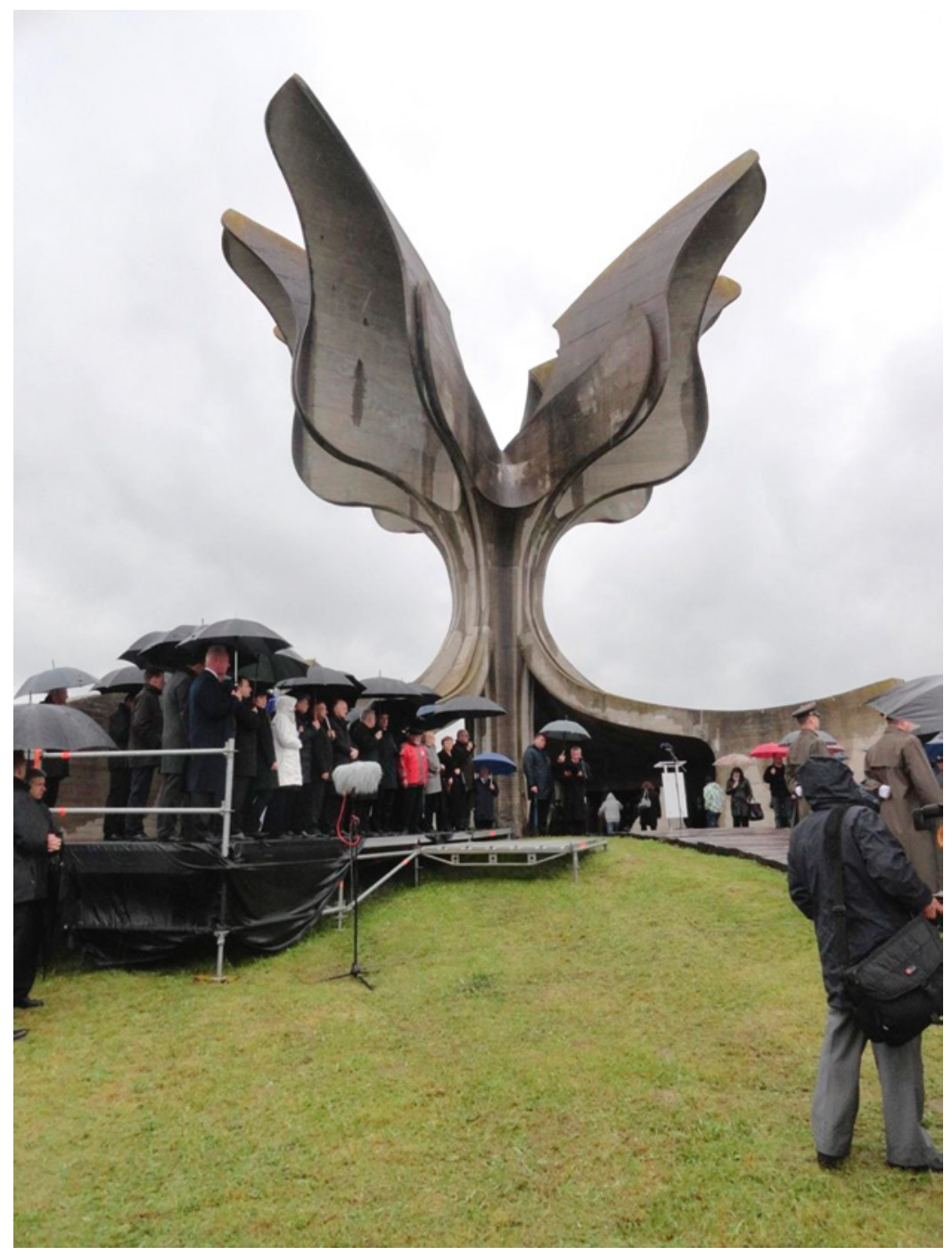

FIGURE $12.1 \quad$ The Jasenovac monument by Bogdan Bogdanović during a commemoration in 2014

PHOTO BY VJERAN PAVLAKOVIĆ

with the help of the United States Holocaust Memorial Museum in 2000, and were finally returned to Croatia in 2001 (Mataušić 2006: 54). ${ }^{28}$

28 Mataušić, "The Jasenovac Concentration Camp," 54. Croatian authorities estimate that about $30 \%$ of the collection, which in 1991 consisted of some 14,000 objects and 2,500 publications, is still missing. It is believed to be in Bosnia-Herzegovina or Serbia. 
As part of his general political platform of restoring Croatia's antifascist legacy, former president Stjepan Mesić (2000-2010) annually attended the Jasenovac commemoration (in honor of the final breakout attempt by the remaining camp prisoners on 22 April 1945), where he often gave fiery commemorative speeches praising the Partisan resistance movement and condemning attempts at rehabilitating the NDH. As Croatia drew closer to EU membership, even the HDZ, under former Prime Minister Ivo Sanader, understood that the country needed to adopt European paradigms of remembrance, particularly in relation to the Holocaust. ${ }^{29}$ In 2006 a new exhibition space was opened at the memorial site, and Sanader, Prime Minister at the time, described what Jasenovac meant to Croatia from a clear European perspective:

We must speak about a Europe without divisions precisely at Jasenovac. Because Jasenovac is a tragic measure of the depth of divisions which, in the context of the old conflicted Europe, were carved deeply into the tissue of Croatian society. Few countries in Europe felt and suffered so much from the consequences of European divisions and conflicts between ideologies and peoples. In the Homeland War we overcame those divisions, we strengthened our antifascist foundations while simultaneously condemning communist totalitarianism, and we raised the paradigm of a newly united and reconciled Croatia that is our pledge in the new Europe. That new Europe brings values that are also part of our inheritance, such as dialogue, tolerance, peace and democracy. Modern Croatia will be built on exactely those values. ${ }^{30}$

Mesić's successor, Ivo Josipović (2010-2015), and the coalition government led by the Social Democratic Party (SDP) continued the commemorative practices at Jasenovac which included explicit condemnation of the NDH and Ustaše, references to EU values, and recognition of the Croatian antifascist contribution to the Allied victory in the Second World War (see Figure 12.1).

The election of the HDz's candidate for president in 2015, Kolinda Grabar-Kitarović, precipitated a shift in the discourse used at Second World War commemorations that paralleled a more general trend in attempts by right-wing politicians and intellectuals to undermine Croatia's antifascist legacy. In April 2015, President Grabar-Kitarović chose to break the practice

29 Ljiljana Radonić, "Univerzalizacija holokausta na primjeru hrvatske politike prošlosti i spomen-područja Jasenovac," in Suvremene teme, vol. 3, no. 1 (2010).

30 Ivo Sanader at Jasenovac, 27 November 2006, https://vlada.gov.hr/vijesti/jasenovacotvoren-memorijalni-muzej-i-obrazovni-centar/5524. 
of her predecessors and did not attend the commemoration of the Jasenovac victims (she had laid a wreath at the site several days earlier). She took several other symbolic actions soon after becoming president, such as removing a bust of Tito from the presidential office (which even Tuđman had kept) and then sponsoring the Bleiburg commemoration in May, which the SDP coalition had previously stopped funding because of the perception among the Left that it contributed to the rehabilitation of the Ustaša movement. The electoral campaign prior to parliamentary elections in the fall of 2015 were notable for the HDZ's virulent anti-communist discourse, threats of imminent lustration and the decision to include parties openly sympathetic to the Ustaše in their coalition. Once the HDZ was able to form a government in early 2016, many of its initial moves seemed to confirm fears that the radical right wing of the party was pushing an ideological agenda mirroring the developments in some other Central European countries such as Hungary, Poland and Slovakia. Some of the first decisions of the new government were to appoint a controversial (some would say revisionist) historian, Zlatan Hasanbegović, as the minister of culture, restore parliamentary sponsorship over the Bleiburg commemoration, and propose to change the name of the parliament to the name it had during the NDH (Hrvatski državni Sabor).

Furthermore, the government did not react when demonstrators marched and threatened the electronic media council while shouting fascist slogans $(\mathrm{Za}$ dom spremni, the Ustaša motto meaning 'Ready for the Homeland'), because it had punished a broadcaster for hate speech against minorities, and turned a blind eye on threats and even physical attacks on representatives of the Serb minority and independent journalists. The general atmosphere was additionally poisoned by a sustained media campaign in the right-wing press discrediting the numbers of victims at Jasenovac, which included references to the annual Jasenovac commemoration as a 'Demonic Dance of Red Bandits' (see Figure 12.2). ${ }^{31}$ Right-wing weeklies, such as Hrvatski tjednik, Hrvatsko slovo and Vijenac, along with publications such as Jasenovački logori (2015), have argued that even the current numbers of victims are greatly exaggerated, andhave further claimed that the 'truth' about the concentration camp is that it allegedly continued to exist as a communist-run camp until 1952 where all of the victims were actually Croats. ${ }^{32}$

31 Hrvatski tjednik, 30 April 2015, front page. The subheading reads "Jasenovac: Magnum crimen against truth and Croatia."

32 The questionable historical methodology and clear ideological agenda of the revisionist camp prompted Slavko Goldstein to respond with his own book countering the claims of 


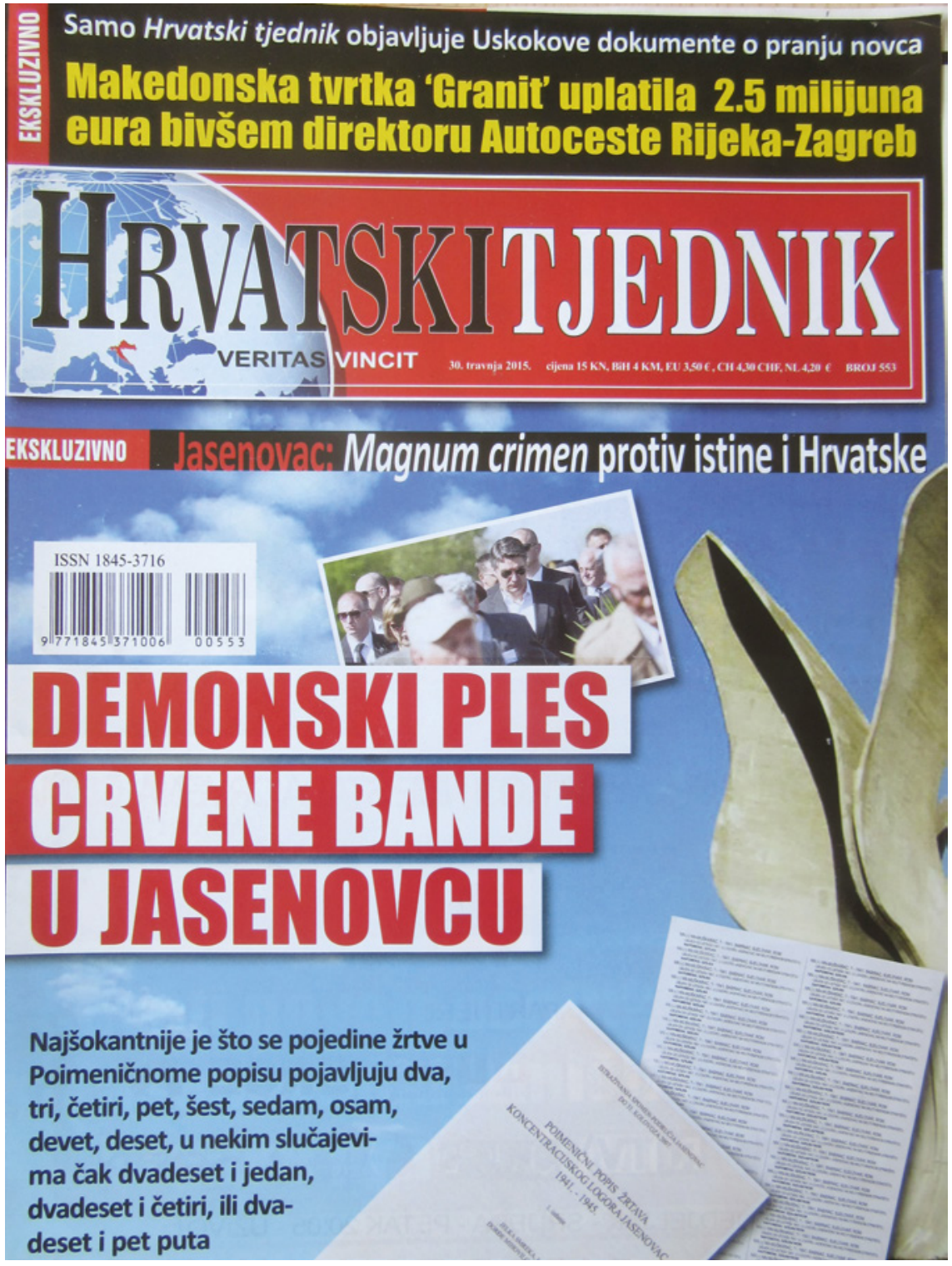

FIGURE 12.2 Cover of right-wing weekly Hrvatski tjednik referring to the Jasenovac commemoration as a 'Demonic Dance of Red Bandits'.

In April 2016, the premier of Jakov Sedlar's revisionist film, Jasenovac - Truth, which included several falsifications identified by investigative journalists, was

the Society for Jasenovac Camps (Društvo Jasenovačkih logora), titled Jasenovac: tragika, mitomanija, istina (Zagreb: Fraktura, 2016). 
the straw that broke the camel's back and spurred an outcry from human rights NGOs, the Serb minority, Roma and Jewish organizations, the antifascist association of Croatia and even the Israeli ambassador. ${ }^{33}$ Consequently, all of these groups boycotted the official commemoration, resulting in an international scandal. While the official commemoration was held on 22 April, attended primarily by government ministers and parliamentary deputies, alternative commemorations were held on 15 April (organized by Croatia's Jewish community) and on 24 April (organized by the Association of Antifascist Veterans of Croatia and the Serbian National Council), along with a protest in Zagreb organized by civil society NGOs on the same day as the official event. The rival interpretations of the nature of the Jasenovac camp were thus present not only in academic publications and the media, but in a number of commemorative rituals and official government statements. It is after this context of contested narratives in the public sphere during March and April 2016 that the respondents of the study were asked to comment on the affective and cognitive features of the Jasenovac memorial.

\section{Jasenovac Conceptualizations and Affective Engagement Case Study}

In the following sections we will present the findings of the research on emotional and cognitive responses after the exposure to the Jasenovac monument representation (Illustration 2), as well as the speeches from commemorations and media appearances given by three memory-producing actors:

a) Zoran Milanović, the former president of the Social Democratic Party of Croatia (SDP), who was, at the time of the speech at the Jasenovac commemoration (26 April 2015), Prime Minister of Croatia. ${ }^{34}$

b) Igor Vukić, a revisionist historian and contributor to the controversial book Jasenovački logori, who appeared in the talk show 'Bujica' in April $2015 .^{35}$

33 Jutarnji list, 8 April 2016, p. 5. The Israeli ambassador to Croatia, Kalay Kleitman, stated that after seeing the film she felt that it "selectively depicted history, attempted to revise many known historical facts, and offended the feelings of people who lost their loved ones in Jasenovac."

34 Link to the speech: https://www.youtube.com/watch?v=hSMyMsirFUA.

35 Link to the appearance in talk show "Bujica": https://www.youtube.com/watch?v=474 HxDhKWm8. 
TABLE 12.1 The structure of the participants in the Jasenovac study.

\begin{tabular}{llll}
\hline Sum & Milanović & Vukić & Vučić \\
\hline 126 & 57 & 41 & 18 \\
\hline
\end{tabular}

c) Aleksandar Vučić, who was, at the time of the speech at the memorial centre Donja Gradina (19 April 2015), Prime Minister of Serbia. ${ }^{36}$

In order to measure the effects of the speeches on the affective and cognitive engagement, we conducted an experimental study using a questionnaire ${ }^{37}$ with 126 participants, mostly students from the University of Rijeka, Faculty of Humanities and Social Sciences, during April 2016. They were distributed in three groups according to the approximately five minute-long speeches delivered by either Milanović, Vukić or Vučić (see Table 12.1).

This paper will focus on the results of the questionnaires from the groups who observed the speech by Milanovićs ${ }^{38}(\mathrm{M})$, the interview with Vukić39 (V) and the speech by Vučić (Vč). ${ }^{40}$ The questionnaire was conducted in the following phases: (1) general questions, (2) presentation of the monument, (3) questionnaire with 21 dimensions measuring affective appraisal and stance, (4) presentation of the speech, (5) reiteration of the questionnaire from phase 3 .

\section{Phase 1: General Questions}

The first phase of the questionnaire recorded seven categories: age, sex, education, profession, nationality, political affiliation, faith, stance on abortion and stance on gay marriage as well as stance on the theory of evolution. The average age of the participants was 21.8 years, of whom $83 \%$ were women and

36 Link to the speech: https://www.youtube.com/watch?v=lIvK8qzg-G4.

37 The questionnaires can be found on the following web-addresses:1) Vukić https://docs. google.com/forms/d/1Un5i3gKEYo_M7x7jDPQyAm3hVqoTIonog33yLoKfuk2) Milanović https://docs.google.com/forms/d/1aZodqwYREIXPQQFxjVJPkiixnjOyjCRUKNVSnson Kf 43) Vučić https://docs.google.com/forms/d/1ynhosIZIVXHwNlyoVD2FoCinywDGIDJB $5 J I_{3} m_{3} \mathrm{G}_{4} \mathrm{Qk}$.

38 The summary of the answers: https://docs.google.com/forms/d/1aZodqwYREIXPQQFxjV JPkiixnjOyjCRUKNVSnsonKf 4 /viewanalytics ).

39 The summary of the answers:https://docs.google.com/forms/d/1Un5i3gKEYo_M7x7jDPQy Am3hVqoTIonog3YYLoKfukY/viewanalytics.

40 As the results have shown, the Vučić group needs more subjects to be statistically relevant. However, we have included the results in the presentation of the study. 
$17 \%$ men. The subjects were mostly students of the University of Rijeka studying Pedagogy 25\%, Cultural Studies 30\%, Psychology 27\%, English language and literature $5 \%$, Polytechnics $6 \%$ : with $56 \%$ undergraduate, $36 \%$ graduate, and $5 \%$ doctoral studies, while $1 \%$ were high school students.

Regarding national identity, $93 \%$ of the subjects declared themselves Croats, $2 \%$ Serbs and $5 \%$ remained nationally undeclared. As to the political affiliation, $73 \%$ declared themselves undecided, $16 \%$ opted for the Social Democratic Party, $5.3 \%$ for Živi zid, $2 \%$ for MOST, and under $1 \%$ for other parties (including, interestingly, the HDz, which, at the time of writing, has the highest number of seats in the Croatian parliament). Regarding the faith, $54 \%$ declared themselves Roman Catholics, $25 \%$ Agnostics, $16 \%$ Atheists, $2 \%$ Muslims, and under $1 \%$ Buddhists and Hindus.

The last few questions were included to reveal some deeper socio-cultural aspects of the subject's belief values. On the question of abortion, $82 \%$ opted for the legalization of abortion and the freedom of a mother's choice, while $12 \%$ expressed a firm stance in favour of banning abortion with pro-life arguments. The distribution for the question on marriage issues was similar, with $90 \%$ supporting the legalization of homosexual marriages, and $9 \%$ exclusively in favour of heterosexual marriages only. On the question of evolution, $26 \%$ thought evolutionary theory to be a scientific paradigm that proves religious beliefs incorrect and is therefore unfit to be taught in schools, $50 \%$ considered the theory a paradigm that should be taught in schools on a different and separate level from religious theories, while $21 \%$ believed evolutionary theory to be equally valid to the religious creationist theory.

\section{Phase 2: Presentation of the Monument}

In the second phase of the research design we exposed the participants to a photograph of the Jasenovac monument (Figure 12.3) for a period of one minute without any additional information about the memorial site.

\section{Phase 3: Questionnaire with Sixteen Dimensions Measuring Affective Appraisal and Stance}

In order to measure the affective response to the illustration, we formulated a questionnaire with sixteen dimensions as dependent variables that indicate the level of emotional engagement and cognitive appraisal. The dimensions were selected in accordance with the theoretical assumptions of componential process model (CPM) of emotion mechanisms. ${ }^{41}$ The CPM claims emotions to

$41 \quad$ Klaus Scherer, "Emotions are emergent processes: they require a dynamic computational architecture," Philosophical Transaction of the Royal Society, 364, (2009), 3459-34747. 


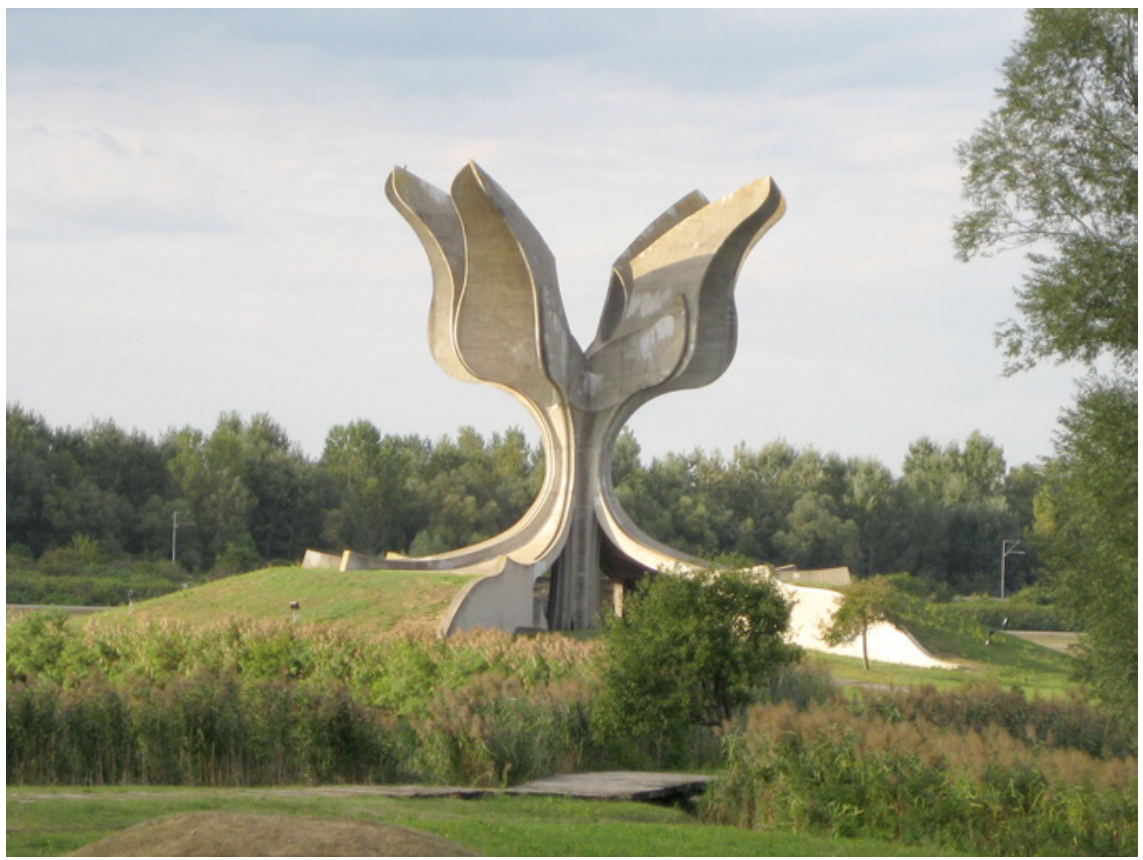

FIGURE 12.3 Image of the Jasenovac monument used to elicit reactions in subjects.

be dynamic and emergent processes arising from interaction of the organism with its environment and direct interaction with higher cognitive processes. The questions in the questionnaire are classified in features of arousal, hedonic valence with pleasantness and unpleasantness dimensions, six emotion categories of fear, shame, anger, disgust, pride, happiness, love, three normative appraisals expressing congruence of the representation with one's self values, and two behavioural tendencies to promote or to dismantle the monument (see features in Table 12.2). The question was formulated in the following manner: 'By looking at the monument I feel: X [Feature]'. The subjects evaluated the occurrence of a particular feature elicited by the representation of the monument ona five-point Likert scale with the following labels: 1 - strongly disagree, 2 - disagree, 3 - neither agree nor disagree, 4 - agree, and 5 - strongly agree. Table 12.2 presents the results of the evaluation after the initial exposure to the image of the Jasenovac monument (Figure 12.3).

The aggregate data for all three groups of subjects $(n=126)$ (Table 12.3) show that initial elicitation with the image of the Jasenovac monument resulted in the neutral activation of the behavioural tendency to keep and promote the monument $($ mean $=3.27, \mathrm{SD}=1.14)$. Slightly negative results were recorded for 
TABLE 12.2 The results of emotional engagement and cognitive appraisal elicited by the Jasenovac monument representation, measured by the five-point Likert scale for three sets ('Milanovic', 'Vukic', 'Vučic') across sixteen features. The column 'Sum' shows aggregate of all three sets. The measure of mean (or average) shows the most common value on a Likert scale, while standard deviation is a measure that quantifies the amount of variation of a set of data values.

\begin{tabular}{|c|c|c|c|c|c|c|c|c|}
\hline \multirow[b]{2}{*}{ Feature } & \multicolumn{2}{|l|}{ Sum } & \multicolumn{2}{|c|}{ Milanović } & \multicolumn{2}{|l|}{ Vukić } & \multicolumn{2}{|l|}{ Vučić } \\
\hline & Mean & SD & Mean & SD & Mean & SD & Mean & SD \\
\hline Disgust & 2.12 & 1.21 & 2.21 & 1.22 & 1.73 & 1.07 & 2.41 & 1.33 \\
\hline Love & 1.81 & 1.01 & 1.79 & 1.00 & 1.83 & 1.02 & 1.82 & 1.01 \\
\hline Anger & 2.49 & 1.37 & 2.60 & 1.28 & 2.22 & 1.37 & 2.65 & 1.46 \\
\hline Unpleasantness & 2.66 & 1.23 & 2.84 & 1.19 & 2.20 & 1.25 & 2.94 & 1.25 \\
\hline Pride & 2.18 & 1.14 & 2.28 & 1.13 & 2.07 & 1.17 & 2.18 & 1.13 \\
\hline Happiness & 1.72 & 0.94 & 1.68 & 0.95 & 1.71 & 0.84 & 1.76 & 1.03 \\
\hline Shame & 2.19 & 1.14 & 2.49 & 1.14 & 1.78 & 1.13 & 2.29 & 1.16 \\
\hline Fear & 2.10 & 1.22 & 2.30 & 1.24 & 1.76 & 1.18 & 2.24 & 1.25 \\
\hline Sadness & 2.84 & 1.39 & 2.79 & 1.28 & 2.68 & 1.46 & 3.06 & 1.43 \\
\hline Pleasantness & 2.08 & 1.03 & 2.09 & 0.95 & 2.02 & 0.96 & 2.12 & 1.17 \\
\hline Arousal & 2.44 & 1.15 & 2.33 & 1.11 & 2.46 & 1.21 & 2.53 & 1.12 \\
\hline $\begin{array}{l}\text { Monument promotes values in } \\
\text { accordance with my values }\end{array}$ & 2.41 & 1.09 & 2.67 & 1.01 & 2.39 & 1.24 & 2.18 & 1.01 \\
\hline $\begin{array}{l}\text { Monument inspires me to promote } \\
\text { my identity and values }\end{array}$ & 2.35 & 1.20 & $2.5^{8}$ & 1.13 & 2.07 & 1.10 & 2.41 & 1.37 \\
\hline $\begin{array}{l}\text { Monument inspires me to question } \\
\text { my identity and values }\end{array}$ & 2.28 & 1.29 & 2.63 & 1.28 & 1.85 & 0.99 & 2.35 & 1.62 \\
\hline $\begin{array}{l}\text { Behavioural tendency: deinstall } \\
\text { the monument }\end{array}$ & 1.75 & 0.97 & 1.93 & 1.05 & 1.68 & 0.93 & 1.65 & 0.93 \\
\hline $\begin{array}{l}\text { Behavioural tendency: keep and } \\
\text { promote the monument }\end{array}$ & 3.27 & 1.14 & 3.23 & 1.13 & 3.29 & 1.08 & 3.29 & 1.21 \\
\hline
\end{tabular}

affective arousal, emotional categories of sadness, unpleasantness and anger, as well as cognitive appraisals expressing the congruence of monument symbolic value with self-identity and social values. On the other hand, the participants disagreed that the representation elicited affective categories of disgust, love, happiness and a behavioural tendency to dismantle the monument. Overall, the initial static visual stimulus activated a somewhat expected neutral and 
TABLE 12.3 The aggregate mean results for all three groups (Milanović, Vukić, Vučić) (n=126) on the five-point Likert scale questionnaire after exposing the subjects to the illustration of the Jasenovac monument. The results are ordered in descending values. The thin lines on the histograms indicate the amount of standard deviation.

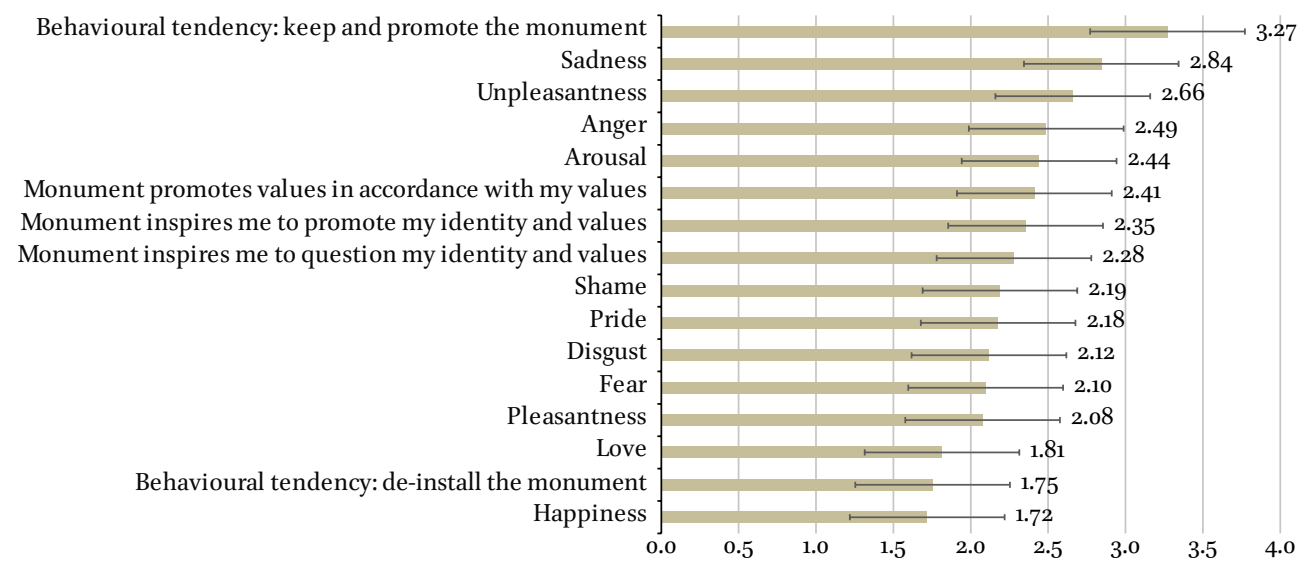

low-level affective engagement and cognitive appraisal in the respondents given the fact that the assessment was conducted in simulated experimental settings. However, the structure of the results shows the salient features of affective and cognitive dimensions elicited by the 'shallow' image representation of the Jasenovac commemoration memorial.

After this evaluation we asked the subjects whether they recognized the monument in the illustration. Around two-thirds of the participants (66\%) recognized the monument, mostly from the media (40\%), but also from elementary school (16\%), high school education (16\%), and college (4\%). Less than $1 \%$ answered that they had some personal connection to the historical events this monument represents. The rate of recognition is somewhat low considering the great historical importance of the commemoration site in Croatian history and the level of media exposure.

\section{Phase 4: Presentation of Political Speeches}

In the fourth phase of the experiment, we exposed our participants to a speech related to the Jasenovac monument by one of the following memory actors: Igor Vukić, ${ }^{42}$ Zoran Milanović ${ }^{43}$ and Aleksandar Vučić (Figure 12.4). ${ }^{44}$

\footnotetext{
42 https://www.youtube.com/watch?v=RaVpllXFi6g.

43 https://www.youtube.com/watch?v=hSMyMsirFUA.

44 https://www.youtube.com/watch?v=lIvK8qzg-G4.
} 


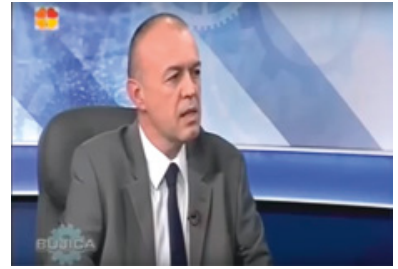

FIGURE 12.4 Igor Vukić

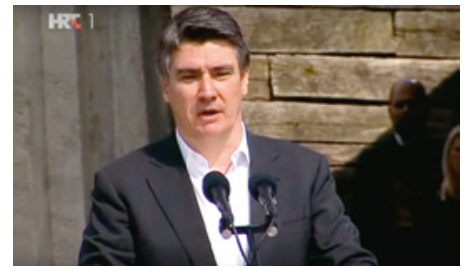

FIGURE 12.5 Zoran Milanović

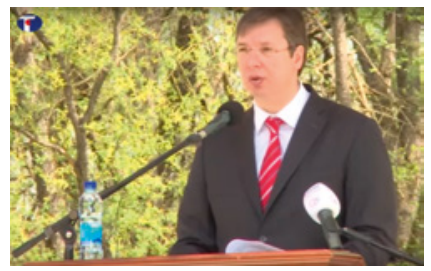

FIGURE 12.6 Aleksandar Vučić

Although the respondents had some previous knowledge of the Jasenovac memorial from either the media or school, and had an opportunity to indicate their emotions based on the visual image of the memorial, the content of the video clips of Milanović, Vukić and Vučić provided specific information of diametrically opposed interpretations of the nature of the concentration camp and its current role as a memorial space. Milanović's talk was antifascist and pro-Croatian, while Vukić's arguments could be summarized as anti-communist and pro-Croatian. Vučić's speech had strong anti-Ustaša and pro-Serbian tones.

The speech by former Prime Minister Milanović can be seen as a continuation of the narrative Croatian political elites have been transmitting at Jasenovac since 2000. He emphasized, even more than in previous years, the important role of Croatian Partisans (including Croats, Serbs and other nationalities) in defeating fascism, and cited the importance of antifascism in the Croatian Constitution. This focus on defending the legacy of antifascists from Croatia, more so than reflecting on the victims of the concentration camp, is clearly a response to the pressure from the HDz's anti-communist rhetoric and the decision of President Grabar-Kitarović to avoid the commemoration. Milanović also used the opportunity to criticize the rehabilitation of the Ustaše at the Bleiburg commemoration and the frequent chanting of the Ustaša motto 'Za dom spremni' (Ready for the Homeland) at football matches. He then ended the speech in a very fiery and patriotic manner, shouting 'Long live Croatian antifascism, long live a modern and humane Croatia!' Viewers were thus presented with a Jasenovac memorial which represented Croatian resistance to fascist ideology and a patriotism that included all regions of Croatia (Milanović repeatedly referred to various parts of the country and their contribution to the Partisan movement).

Igor Vukić's interview attempts to paint a much different picture of the Jasenovac camp than he promotes in his publications and many media appearances. Vukić and several like-minded historians claim that in addition to exaggerating the number of victims killed at Jasenovac by the Ustaše, the 
communist regime constructed lies to cover up that the true mass murders took place after 1945 when the camp was used to hold defeated Ustaše forces, and later Cominform supporters considered to be on the wrong side of the Tito-Stalin split. ${ }^{45}$ His approach is not to build upon the internationally accepted historiography, but to automatically dismiss all previous research as lies and deliberate manipulations, all with the goal of demonizing Croats and the Croatian people. He attempts to illustrate the benign nature of Jasenovac, which he claims was a work camp and not a death camp, with a story of Ustaše guards playing with his father (a Serb) when the latter was a child. This is in line with his publications ${ }^{46}$ in which he argues that witnesses do not mention seeing any Roma prisoners other than some circus performers (the approximately 8,000-15,000 Roma victims were most often immediately killed upon arriving at the camp complex), ${ }^{47}$ that many Jews were in fact protected by the Ustaša regime (a rather perverse argument considering that it was the Ustaša regime that enacted anti-Semitic laws immediately upon coming to power, resulting in an estimated 10,000-13,000 Jewish victims in the Jasenovac camp alone $)^{48}$ and that Serbs were sent to the camp only if they resisted the Ustaša regime as Četniks or Partisans (not only were the majority of Serb victims civilians, the Ustaše labelled practically all Serbs Četniks, a practice continued in Croatian nationalist circles to this day). ${ }^{49}$

Vukić's overall argument is that Jasenovac is one of the main symbols of the falsifications constructed by the communists to paint the Ustaše as mass murderers and justify their own authoritarian regime. Vukić presents the Jasenovac memorial as a place that leftist politicians use for manipulating the public in order to promote a communist, pro-Yugoslav, and anti-Croat political

45 Slavko Goldstein has convincingly debunked the conspiracy theories presented in the publications by Vukić and others who support the 'three camp theory' in his bookJasenovac: tragika, mitomanija, istina (2016).

46 Igor Vukić, "Sabirni i radni logor Jasenovac, 1941-1945," in Stjepan Razum and Igor Vukić, eds., Jasenovački logori: istraživanja (Zagreb: Društvo za istraživanje trostrukog logora Jasenovac, 2015), 132-134.

47 Narcisa Lengel-Krizman, "The Genocide Carried out on the Roma - Jasenovac 1942," in Rimay, Jasenovac, 168-169.

48 Ivo Goldstein, Holokaust u Zagrebu (Zagreb: Novi liber, 2001), 302-343.

49 Drago Roksandić, "Of Tragedy, Trauma, and Catharsis: Serbs in the Jasenovac Camp, 1941-1945," in Rimay, Jasenovac, 86-89. Roksandić notes that 'in many cases the Ustashas [sic] preferred to classify the Serbian inmates, particularly the elderly, as Chetniks, even when it was obvious they had no connections with Chetniks.' Ibid., 87 . 
agenda. The reception of the messages sent by these two opposed video clips are reflected in the second set of responses to the image of the memorial by the different emotional reactions.

Aleksandar Vučić's talk paints the opposite picture to that presented in Vukić's interview. With a rhetorically confident and emotionally conducive tone he portrays the savageness and ruthlessness of the Ustaša crimes that were committed in the Jasenovac camp against Serbs. The allegorical picture of the Serbian suffering is demonstrated by the vivid depiction in his speech at Donja Gradina of a child's head being crushed by an Ustaša guard and the use of knives to slaughter prisoners. The rhetorical twist is produced when Vučić declares that the Ustaša's extermination plan was not successful, praising the resiliency of the Serb people and their bright future, without any need for expansionism but with a need to firmly control their territory. With the skillful activation of the main conceptualizations of the Serb-Croat conflict from the perspective of Serbian politics, the main goal of this talk was to praise the Serbian people while simultaneously profiling Croatia, a geopolitical rival and EU member, in terms of Ustaša crimes.

\section{Phase 5: Stance towards the Speaker and the Message}

In the research design we included questions measuring the stance towards the speaker and his message, measuring qualitative and quantitative values. The quantitative dimensions were again measured with the same five-point Likert scale (Table 12.4).

Table 12.4 shows the mean values and standard deviation of evaluations regarding two questions: (a) do you have positive attitude towards the speaker? and (b) do you agree with the content of their message? The results indicate

TABLE 12.4 Attitudes towards the speaker and the message expressed in measures of mean and standard deviation $(S D)$.

\begin{tabular}{lllllll}
\hline & \multicolumn{2}{c}{ Milanović } & \multicolumn{2}{c}{ Vukić } & \multicolumn{3}{c}{ Vučić } \\
\cline { 2 - 7 } & Mean & SD & Mean & SD & Mean & SD \\
\hline $\begin{array}{l}\text { Positive attitude towards } \\
\text { speaker }\end{array}$ & $\mathbf{3 . 0 8}$ & $\mathbf{1 . 2 3}$ & 2.61 & 1.04 & 2.29 & 1.16 \\
$\begin{array}{l}\text { I agree with the content } \\
\text { M.56 }\end{array}$ & $\mathbf{3 . 0 2}$ & 2.46 & 1.00 & 2.94 & $\mathbf{1 . 3 4}$ \\
\hline
\end{tabular}


that the Milanovic group expressed the highest value of agreement with Milanović as a person (mean $=3.08, \mathrm{SD}=1.23$ ), as well as with the content of Milanović's antifascist message $($ mean $=3.56, \mathrm{SD}=1.02)$. Personal attitudes towards Vukić were slightly lower. Subjects in the Vučić group had the most negative attitudes regarding Serbian Prime Minister Vučić, but his message was valued as neutral. Interestingly, Vučićs anti-Ustaša message scored a relatively higher level of agreement than Vukić's pro-Ustaša revisionist message about the Jasenovac site.

In order to gain some qualitative insight about the reception of conceptualizations in the speeches we asked subjects to write down the prominent ideas they observed in the speech and the most emotive phrases they remembered. The following examples (1-3) illustrate the prominent idea detected by the subjects in Milanovićs talk.

1) Moderna Hrvatska država nije osnovana na idejama tadašnje formirane NDH, već je upravo utemeljena na otporu takvoj politici i propagandi. $\mathrm{Hr}$ vatska prema tome ne podržava veličanje nacionalizma, već za cilj ima jednakost, bez obzira na nacionalnost.

'The contemporary Croatian state is not based on the ideas of the $\mathrm{NDH}$, but on the resistance towards such politics and propaganda. Croatia, therefore, does not support nationalism but has equality as its goal, regardless of nationality.'

2) Najviše me emotivno probudilo kad je spominjao Bleiburg i Jasenovac, te kada je pričao o partizanima u svojoj obitelji, jer su i moji preci bili u partzanima.

'I was emotionally moved when he mentioned Bleiburg and Jasenovac, and when he spoke about the Partisans in his family, because my ancestors were also Partisans.'

3) živjela antifašistička Hrvatska

'Long live antifascist Croatia'

Some of the highlights from Milanovićs talk include the prototypical national messages with the aim to bolster national pride connected with the antifascist resistance (3), denunciation of the Ustaša regime (1) and recent attempts to reintegrate the Ustaša salutation 'Za dom spremni' into popular nationalist repertoire. Some of the participants have related the message with their family Partisan history (2), which made the talk more emotional and meaningful for them. However, some of the participants clearly state the need to leave this futile rhetoric and divisions in the past, perceiving it as primitive division of the Croatian people. 
Example (4) illustrates the predominant understanding of the main idea in Vukić's talk.

4) logor uJasenovcu je bio radni logor, a ne logor smrti

'The Jasenovac camp was a work camp, not a death camp.'

In Vukić's talk the most interesting conceptualization is construed by the narrative depicting his father playing with Ustaša soldiers in Jasenovac (5). This particular scene frames the whole event with an emotional flavor of cheerfulness intended to support a cognitive conceptuali of Jasenovac as a work camp, and not a death camp (4). This positive manipulation of the children's frame and its immediate affective - cognitive value is seen as especially important for the construal of the affective load necessary to superimpose the more frequent negative suffering frame connected with the Jasenovac narrative.

5) Moj se otac sjeća kako su ga ustaše nosile na ramenima i igrali se s njim! 'My father remembers how the Ustaše used to carry him on their shoulders and play with him!'

The same conceptualization but with opposite affective valence is skillfully construed in Vučić's talk (6)

6) Kada se spominju djeca i način na koji su krvnici govorili kako će ih ubiti polako.

'When he mentions children and the manner in whichbutchers talk about how they are going to kill them slowly'.

Vučić channels this affective arousal into the main theme as seen by one of the subjects:

7) Nitko neće istrijebiti Srbe koji su duhovno i intelektualno nadmoćniji jer vide veličinu svojih žrtava i strahotu zločina nad svojim ljudima, a uzdižu se iznad nje - ne osvećuju se, ali pamte i prkosno stoje iznad svih!

'No one will exterminate Serbs that are spiritually and intellectually superior because they see the greatness of their own victimhood and the horror of the endured crimes and still rise above it all - they do not take revenge, but remember and dare to stand above them all!'

It is beyond the scope of this paper to delve into the intricacies of the figurative speech usage that activate the affective states and profile the pragmatic 
inferences in the listener. However, the qualitative paradigm can be noted from the previous examples. The speakers rely on the activation of the affective content and traumatic experiences by use of the embodied metonymic and metaphoric representations of horror, killing, imagery of innocence and children, vivid expressions of brutality, or the opposite heroic images of the sacrifice, pride and playfulness that are conducive to the construal of the more abstract cultural models of nationality ${ }^{50}$ with implicit rearrangement of the social norms and implications for self-identification and emergence of social identity processes. The reception of the linguistically modulated affective processes is qualitatively measured in the next phase of the questionnaire.

\section{Phase 6: Repetition of the Question from Phase 3}

After exposing our participants to the political talks we wanted to see whether the conceptualizations of the commemoration had some immediate effect on the affective and cognitive engagement regarding the Jasenovac monument. In order to determine if there was any change in the respondents' perception of the monument, the questionnaire from Phase 3 with sixteen dimensions was introduced again. This allowed us to measure the difference between pairs of affective dimensions and cognitive appraisal features after the initial decontextualized visual stimulus and then after the speech's contextualized conceptualizations. A paired-sample two-tailed t-test ${ }^{51}$ using software $\mathrm{R}^{52}$ was conducted to compare and measure significant differences in the evaluation results for the sixteen features before and after the exposure to political speeches. The mean difference was then calculated for each feature. The mean difference obtained by the t-test is taken to represent the effect of emotive engagement and appraisal caused by the profiled conceptualizations in the speech. The effects of the speeches by Milanović, Vukić and Vučić, along with the aggregate data, are represented in Table 12.5 and Table 12.6 with mean difference and p-values. ${ }^{53}$

5o Patrick Colm Hogan, Understanding Nationalism: On narrative, Cognitive Science, and Identity (Columbus: The Ohio State University Press, 2009).

$5^{1} \quad$ A paired t-test is used to compare two population means for two samples in which observations in one sample can be paired with observations in the other sample. In this case our subjects had the same set of questions evaluating the engagement with the monument before and after the speech with the five-point Likert scale.

52 https://www.r-project.org/.

53 P-value is defined as the probability of obtaining a result equal to or "more extreme" than what was actually observed, when the null hypothesis is true. If the null hypothesis is true ( $p$ value $=1$ ) means that there is no effect or difference between two measured phenomena. $\mathrm{P}$ values evaluate how well the sample data support the argument that the null hypothesis is true. Following the conventions of the asterisk rating system, we have marked the significant results with the p value $\leq 0.05$ with ${ }^{*}$, $p$ value $\leq 0.01$ with ${ }^{* *}$ and $p \leq 0.001^{* * *}$. 
TABLE 12.5 Effects of affective engagement and cognitive appraisal after the speeches by Milanović, Vukić and Vučić, as well as their aggregate effects. Values represent the mean of differences derived from two sided paired $t$-test and $p$-values $\left({ }^{*} p \leq .05\right.$, ${ }^{* *} p \leq .01,{ }^{* * *} p \leq .001$.) with a $95 \%$ confidence interval.

\begin{tabular}{|c|c|c|c|c|c|c|c|c|}
\hline \multirow[b]{2}{*}{ Feature } & \multicolumn{2}{|c|}{ Aggregate M,V,Vc } & \multicolumn{2}{|l|}{ Milanović } & \multicolumn{2}{|l|}{ Vukić } & \multicolumn{2}{|l|}{ Vučić } \\
\hline & Mean Diff & P-Value & Mean Diff & P-Value & Mean Diff & P-Value & Mean Diff & P-Value \\
\hline Disgust & $0.4^{* * *}$ & 0.0002 & 0.2632 & 0.0874 & $0.6098^{* * *}$ & 0.0003 & $0.35^{29}$ & 0.3028 \\
\hline Love & -0.0434 & 0.5807 & 0.0877 & 0.4028 & -0.0976 & 0.5117 & $-0.35^{29}$ & 0.0546 \\
\hline Anger & $0.4174^{* * *}$ & 0.0002 & $0.315^{*}$ & $0.043^{1}$ & $0.6585^{* *}$ & 0.0033 & 0.1765 & 0.422 \\
\hline Unpleasantness & $0.4173^{* * *}$ & 0.0004 & $0.3684^{*}$ & 0.0299 & $0.6585^{* * *}$ & 0.0004 & 0.0000 & 1 \\
\hline Pride & -0.0956 & 0.4026 & $0.05^{26}$ & 0.7636 & -0.1707 & 0.3602 & -0.4118 & 0.0895 \\
\hline Happiness & -0.1217 & 0.1086 & $-0.035^{1}$ & 0.7606 & -0.1707 & 0.1642 & -0.2941 & 0.0961 \\
\hline Shame & $0.2260^{*}$ & $0.039^{2}$ & -0.0877 & 0.5199 & $0.5^{8} 54^{* *}$ & 0.0017 & 0.41176 & 0.262 \\
\hline Fear & $0.2434^{*}$ & $0.025^{2}$ & $0.035^{1}$ & 0.802 & $0.5^{8} 54^{* *}$ & 0.0029 & 0.1176 & 0.7073 \\
\hline Sadness & $0.5304^{* * *}$ & $5.23 \mathrm{E}-05$ & $0.5965^{* *}$ & 0.0025 & $0.5^{8} 54^{* *}$ & 0.0071 & 0.1764 & 0.5479 \\
\hline Pleasantness & $-0.2086^{*}$ & 0.0319 & -0.1228 & 0.3825 & -0.1463 & 0.3366 & $-0.6470^{*}$ & 0.0226 \\
\hline Arousal & $0.6173^{* * *}$ & $8.45^{\mathrm{E}-09}$ & $0.7544^{* * *}$ & $2.39 \mathrm{E}-07$ & $0.6829^{* * *}$ & 0.0002 & 0.0000 & 1 \\
\hline $\begin{array}{l}\text { Monument } \\
\text { promotes values } \\
\text { in accordance } \\
\text { with my values }\end{array}$ & 0.1391 & 0.1381 & $0.2807^{*}$ & 0.0410 & 0.0488 & 0.6431 & -0.1176 & 0.7498 \\
\hline $\begin{array}{l}\text { Monument } \\
\text { inspires me to } \\
\text { promote my } \\
\text { identity and } \\
\text { values }\end{array}$ & $0.1826^{*}$ & 0.04775 & 0.211 & 0.1591 & 0.1951 & 0.1031 & 0.0588 & 0.8167 \\
\hline $\begin{array}{l}\text { Monument } \\
\text { inspires me to } \\
\text { question my } \\
\text { identity and } \\
\text { values }\end{array}$ & 0.05217 & 0.6192 & 0.0175 & 0.9105 & $0.195^{1}$ & 0.198 & -0.1765 & 0.593 \\
\hline $\begin{array}{l}\text { Behavioural } \\
\text { tendency: deinstall } \\
\text { the monument }\end{array}$ & -0.0956 & 0.2506 & $-0.2281^{*}$ & 0.0313 & $0.073^{2}$ & 0.5838 & -0.0588 & 0.8484 \\
\hline $\begin{array}{l}\text { Behavioural } \\
\text { tendency: keep } \\
\text { and promote the } \\
\text { monument }\end{array}$ & $0.2347^{*}$ & 0.01947 & $0.3158^{*}$ & 0.01297 & 0.2439 & 0.1242 & -0.0588 & 0.8784 \\
\hline
\end{tabular}


TABLE 12.6 An illustration of the effects after the speeches by Milanović, Vukić, and Vučić as measured by $t$-test. The effects are the difference in the mean values of the psychometric five-point Likert scale for each feature, before and after the speech. The green bars represent effects in the Milanović group, red bars in Vukić's and gray ones in the Vučić group.

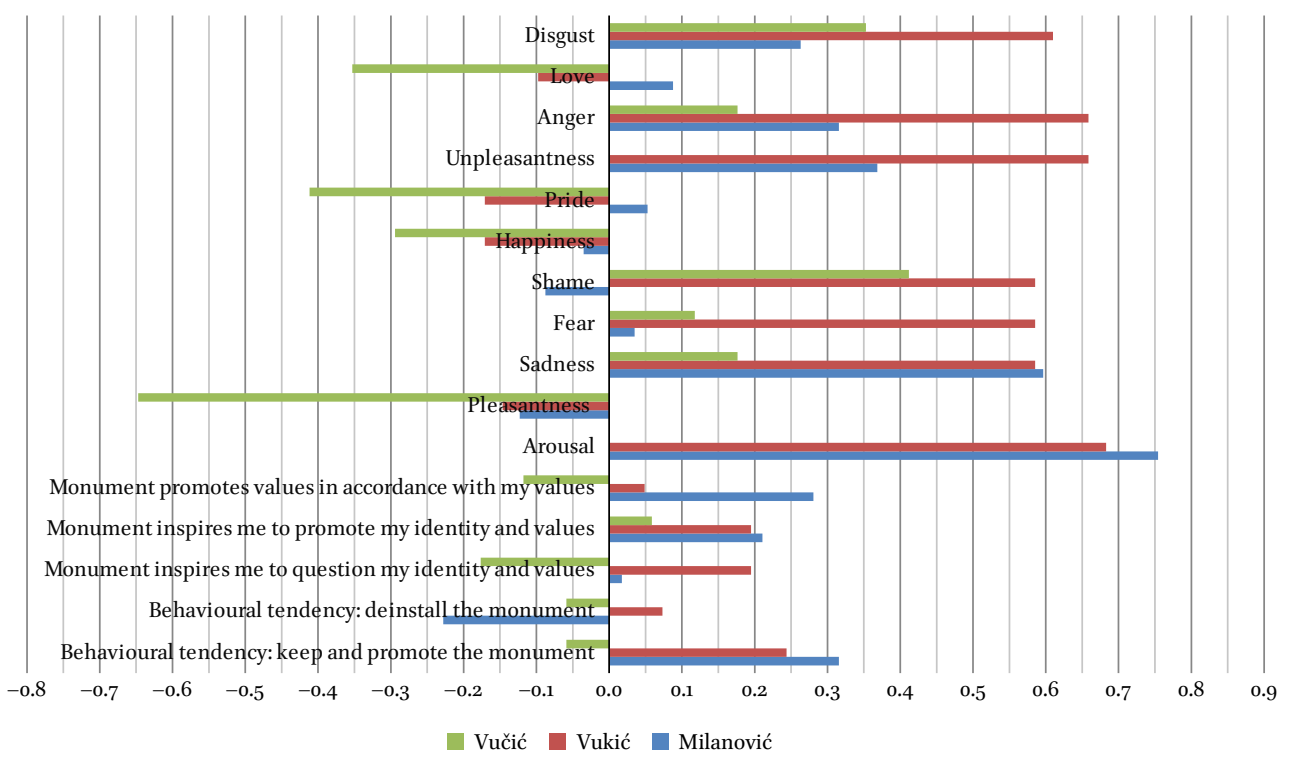

The results show the greatest and statistically significant increase in the emotional dimension of arousal and negative hedonic valence ${ }^{54}$ in three groups: unpleasantness (Tables 12.7 and 12.8), sadness (Tables 12.7 and 12.8), anger (Tables 12.7 and 12.8), fear (Table 12.8) and disgust (Table 12.8). This difference is on a scale of $0.4-0.7$ of a five-point Likert scale. This could be interpreted that, on the average, the effect of the talk was to raise arousal and negative valence by almost $15 \%$. The highest increase in these negative emotions is generated in the Vukić group implying that the revisionist message stimulated a feeling of unease, fear and repulsion, as exemplified by the statement from one of the subjects in this group (8):

8) sve izjave govornika su pobudile ljutnju

'All statements aroused anger.'

54 The ability to experience pleasant or unpleasant feelings, or to represent objects as 'positive' or 'negative', is known as representing hedonic 'valence.' 
The low arousal, negative emotion of sadness also prominently increased in all groups (Tables 12.7 and 12.8), although slightly less in the Vučić group. This difference could be due to the Vučić inability to induce emphatic discourse with his predominantly Serbian nationalistic message, as stated from the questionnaire (9):

9) hrvati su ubijali srbe u jasenovcu. oni su i dalje tu i napreduju.

'Croats killed the Serbs in Jasenovac. They are still here and continue to advance.'

In all groups the positive hedonic valence, pleasantness (Illustration 8) and happiness, decreased. The greatest negative tendency of these emotions is recorded in the Vučić group. This is probably related to the vivid depictions of the atrocities committed in Jasenovac. This is corroborated by speech observation by one of the participants in the Vučić group (10):

10) smrt, teror, ubijanje djece

'death, terror, killing of children'

It is interesting that socially complex emotions, such as pride, shame (Table 12.9) and love, have a different type of directionality in the three groups, showing more correlation with the cognitive models of self-appraisal and social standards.

The negative emotional category of shame tended to decrease after Milanović's speech. This can be seen as one of the intended effects of the commemorative ritual, related to Milanović's conceptualization of Jasenovac as a site of traumatic but transformational memory, connected with the liberation of the camp by the victorious antifascist army and the overthrow of the Ustaša regime (see example 3). The increase of the pride and love dimensions in the Milanović group can be attributed to the same kind of successful conceptualization of the traumatic history and reinforcement of these positive humanistic values in the present that are seen as congruent with self-identity and social values, and the reestablishment of one's identity.

On the other hand, shame tends to increase while love and pride decrease in the Vukić and Vučić groups. The effect of shame dimension in the Vukić group is especially prominent with a statistically significant increase over $0.5^{8}$ in terms of the five-point Likert scale, or $12 \%$. This can be interpreted as the psychological effect of how Vukić construes the Jasenovac narrative from a revisionist position that tends to highlight the two conflicting cultural models of Croatian identity: a nationalist model and an antifascist model. Both of those 
models have been imbued with atrocities committed during the Second World War or during the communist regime. This type of framing and conceptual focus on the rivaling models of the national history correlates with the decrease of pride.

The tendency to positively correlate symbolic representation of the Jasenovac monument and one's own moral values increases slightly for the Milanović group ( 0.28 or $5.6 \%)$ (Table 12.7). This is probably related to Milanović's profiling of the victorious antifascist history and progressive values that resonated with the subjects. On the other hand, questioning one's identity and values tends to be related more with the Vukić group. Vučić's depiction of theUstaša atrocities in Jasenovac seems to have effects on inhibiting identification of the monument with one's values and identity, as well as decreasing rational inquiry of the self-values and social norms.

The behavioural tendencies follow from the affective appraisal process. The Milanović group has a statistically significant increase in tendencies to keep and promote the monument ( 0.3158 or $6 \%)$. This is also observed in the Vukić group. The Vučić group, however, demonstrated a significant decrease of pleasantness and pride, as well as anincrease of shame and fear, resulting in a slight decrease of the tendency to keep and promote the monument. However, it is interesting that, although statistically not significant, the behavioural tendency to dismantle the monument was also heightened in the Vukić group. This small effect can be attributed to the accepted revisionism of the Vukić conceptualizations, but also a statistically significant increase of shame, fear, disgust and unpleasantness (Table 12.8).

In summary, the aggregate data set (Table 12.10) demonstrates that political speeches generated the largest effect size in the affective dimension

TABLE 12.7 Statistically significant effects sizes after Milanovićs speech.

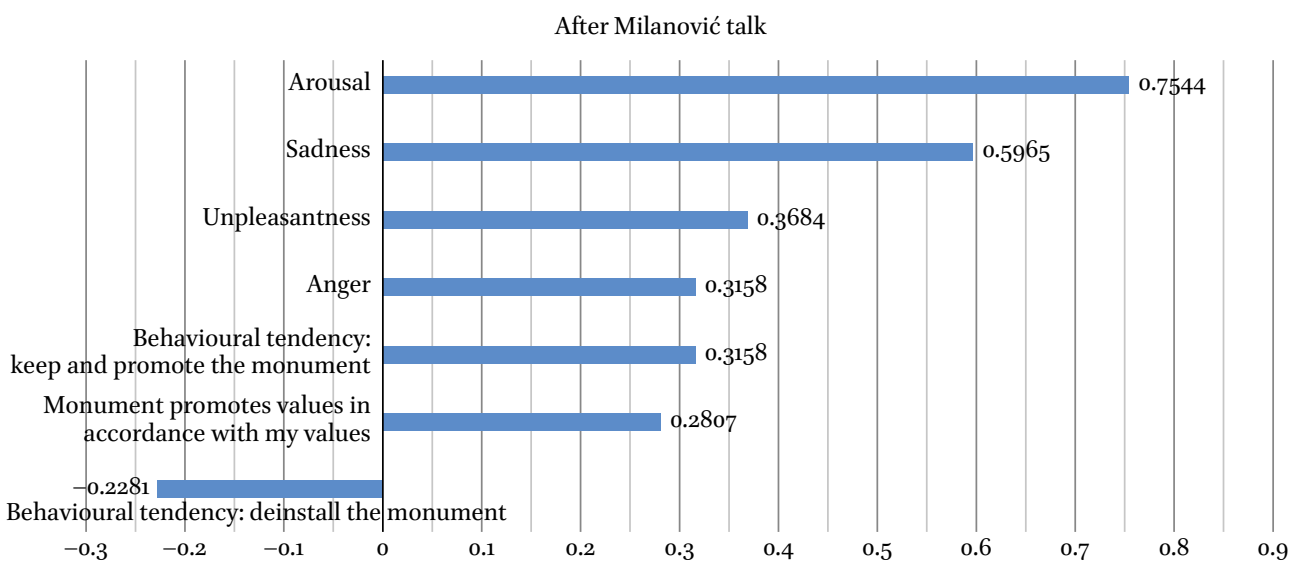


TABLE 12.8 Statistically significant effects sizes after Vukić's interview.

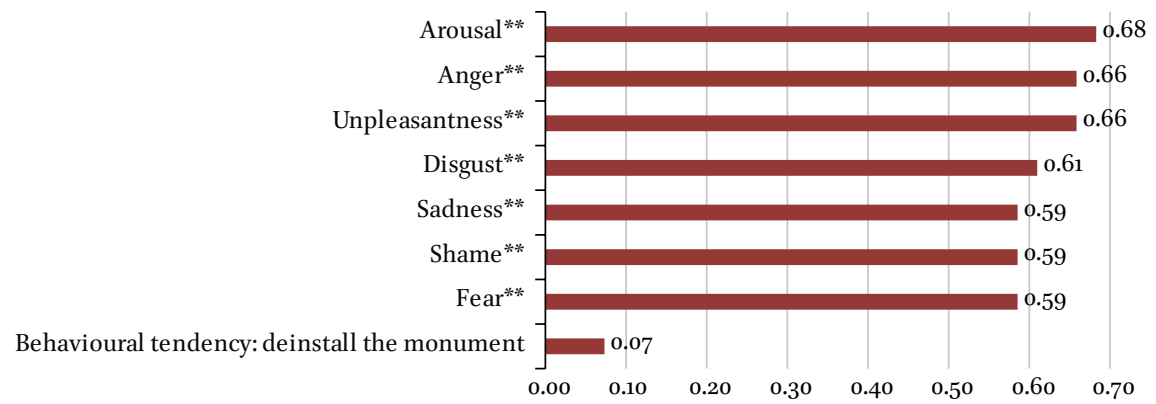

TABLE 12.9 Statistically significant effects sizes after Vučić's speech.

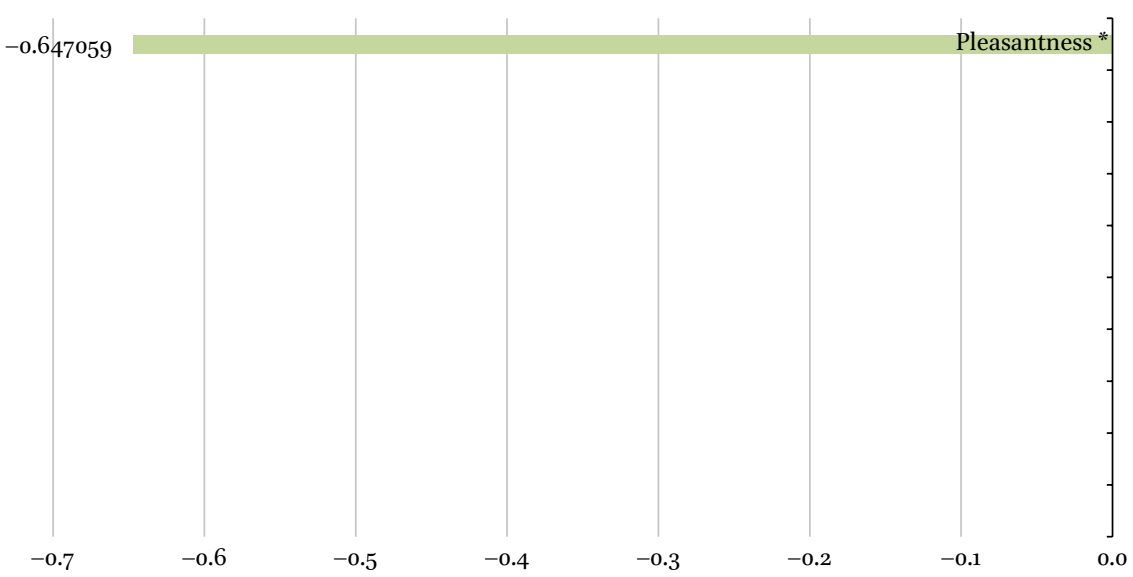

TABLE 12.10 Statistically significant effects sizes after the speeches for the aggregate data set.

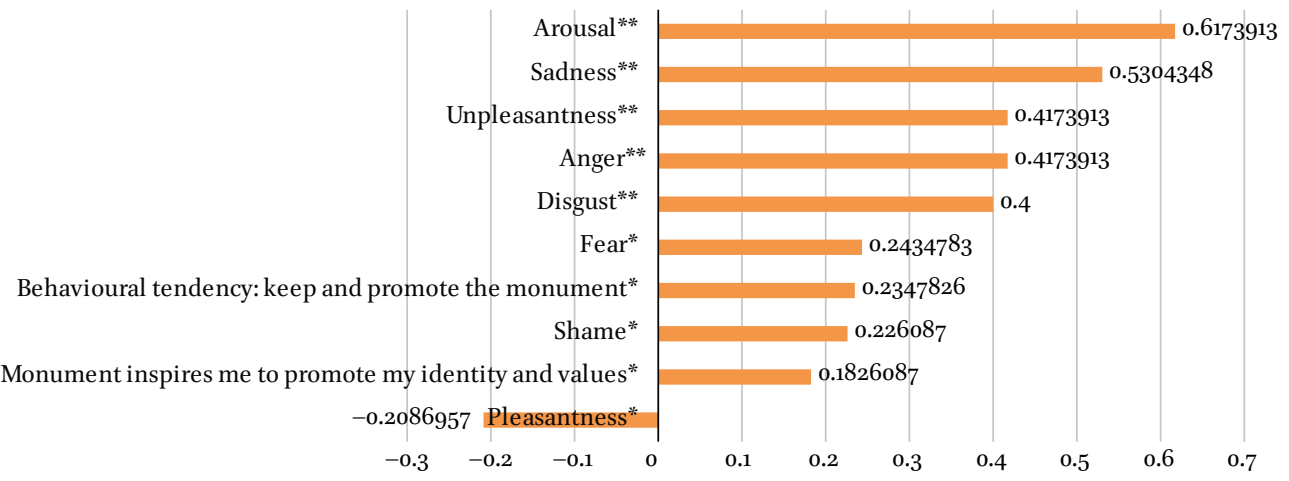


of arousal. Although qualitatively not discriminative, the value of affective arousal is correlated toactivating attention, regulating consciousness and information processing. ${ }^{55}$ The activation of attention is a key factor for the successful transmission of cultural memory, especially its transgenerational dynamics. In other words, if an event does not arouse any affective load, it is likely to be forgotten in the next generation. It can be argued that commemorative rituals have a function to capture the attention of audiences by heightening the affective dimension of arousal. The most common means of creating arousal in traumatic commemoration sites such as Jasenovac is by reconstructing vivid depictions of atrocities. Particularly Vučić, and to a certain extent Milanović, exploited these constructive strategies in their speeches, while Vukić tried to reconceptualize the prototypical Jasenovac representation by introducing the images of a safe childhood within the scenery of an alleged work camp.

The arousal is also correlated with the increase of different emotions. Not surprisingly, the effects of the commemorative speeches were to increase sadness, unpleasantness and intrinsically negative emotions such as disgust, anger, fear and shame. The effects of increased sadness can be interpreted as the measure of the intensified participant's empathy with the victims of the camp. The activation of anger and fear is especially important because of their capacity to motivate reasoning about implications and coping strategies. In our experiment we have deliberately chosen speakers that construed different causal configurations in relation to the traumatic events and implicated different type of rationalizations to channel coping with these negative feelings. Motivation and coping are an important link to framing and establishing different cultural models and social norms. The significant increase of sadness is related to successful conceptualization of the traumatic events, usually elaborated in vivid metonymic and metaphoric expressions that enable receivers to mentally recreate the distress in an embodied manner. Lastly, the contextual conceptualizations promoted the tendencies to keep the monument, implying that their symbolic significance regained new meaning.

55 The relation between arousal and attention has been the subject of extensive research in psychology. See Eysenck Michael, Attention and Arousal: Cognition and Performance (Springer Science \& Business Media, 2012); A. Hunter and J.D. Eastwood, J.D., "Does state boredom cause failures of attention? Examining the relations between trait boredom, state boredom, and sustained attention," Exp Brain Res (2016), 1-10. The CPM theory by Scherer also indicates the correlation of appraisal of relevance and attention. 


\section{Conclusion}

In this chapter we have presented a study intended to experimentally measure the psychological impact of political talks on the affective engagement and conceptualization of the collective remembrance site Jasenovac, symbolically represented by its monument. The Jasenovac site was chosen as a contested commemoration site that political agents use to construct narratives of the Croatian national past, inscribing new meanings into cultural memory through their commemorative rituals. We conducted an experiment with 126 participants and devised qualitative and quantitative methodology to empirically examine their reception of the political ritual uses of Jasenovac memory sites. The three groups of participants were exposed to the image of the Jasenovac monument and then political speeches by three memory agents (Milanović, Vukić and Vučić), all of whom are pushing different narratives about the concentration camp.

The structure of the emotional features reveals somewhat expected distribution for a commemoration event with sadness and unpleasantness in the upper ordinal range and happiness in the lower end. The results of the effect size show the greatest increase in the emotional dimension of arousal, unpleasantness, sadness, anger, fear and disgust. The range $0.4-0.7$ of a five-point Likert scale or almost $15 \%$ effect size for these important features indicates that the commemorative speeches have increased attention, motivation and reasoning about the implications of the commemoration for the national cultural model, which is one of the most important functions of commemorative rituals.

The qualitative textual analysis of political speeches and participant's observations identified narrative strategies of different speakers to construe the cultural memories of this contested memory site. The semantic analysis of responses revealed that effective inter-subjective communication of emotional qualities involved the use of embodied metonymic and metaphoric conceptualization that influence the behavioural tendencies and appraisal of the participant's self and social values. In accord with embodied cognition theory, we argue that affective and cognitive engagement elicited by the memory actors and their narrative practices are important in consolidating, reevaluating and renegotiating cognitive models, values, social identities and cultural memory. With the frequent reinforcement of the message in the media we can hypothesize that effects of this process create culturally distributed collective memory.

Due to the experimental research conditions, the effect sizes are to be taken as tendencies and not as absolute values. We can presume that direct involvement in the commemoration rituals would result in deeper 
psycho-sociological impact due to the more elaborated context. Nevertheless, this study indicates that the dynamics of a cultural memory transmission is correlated with the level of affective and cognitive engagement of the recipients. It also shows the functions of the conceptualizations activated by the memory agents in their speeches for the construal and appropriation of a cultural model and permeating the monument with new symbolic meanings.

The data we gathered enables us to seek even more correlations of dependent variables with other independent variables of age, sex, nationality and education, as well as to perform a qualitative study of the significant linguistic strategies of recreating affective engagement from the perspective of memory transmission and reception. In the future we plan to broaden the pool of respondents, including regional diversity, political orientation and age groups.

\section{Bibliography}

Assmann, Jan. Kulturno pamćenje, trans. by Vlahidin Preljavić. Zenica: Vrijeme, 2005.

Barsalou, L. "Grounded Cognition," in Annual Review of Psychology 59 (2008).

Deverić, Mišo and Fumić, Ivan. Hrvatska u logorima, 1941-1945. Zagreb: Savez antifašističkih boraca i antifašista Republike Hrvatske, 2008.

Fontaine, Johnny R.J., Scherer, Klaus R., and Soriano, Cristiana, eds. Components of emotional meaning: A sourcebook. Oxford: Oxford University Press, 2013.

Frank, Roslyn M. "A future agenda for research on language and culture" in The Routledge Handbook of Language and Culture, edited by Farzad Sharifian, 493-512. London: Routledge, 2015 .

Goldstein, Slavko. 1941. Godina koja se vraća. Zagreb: Novi Liber, 2007.

Goldstein, Slavko. Jasenovac: tragika, mitomanija, istina. Zagreb: Fraktura, 2016.

Grahek Ravančić, Martina. Bleiburg i križni put 1945. Zagreb: Hrvatski institut za povijest, 2009.

Halbwachs, Maurice. On Collective Memory. Trans. by Lewis A. Coser. Chicago: University of Illinois Press, 1992.

Hoare, Marko Attila. Genocide and Resistance in Hitler's Bosnia: The Partisans and the Chetniks, 1941-1943. Oxford: Oxford University Press, 2006.

Horvat, Ivan, Vukić, Igor, Pilić, Stipo and Matković, Blanka. Jasenovački logori: istraživanja. Zagreb: Društvo Jasenovački logori, 2015.

Jambrešić-Kirin, Renata. "Politička sjećanja na Drugi svjetski rat u doba medijske reprodukcije socijalističke culture," in Lada Čale Feldman and Ines Prica, eds. Devijacije i promašaji: Etnografija domaćeg socijalizma. Zagreb: Institut za etnologiju i folkloristiku, 2006. 
Jovičić, Nataša. "The Alchemy of the Flower," in Tea Benčić Rimay, ed.Jasenovac Memorial Site. Jasenovac: Spomen-područje Jasenovac, 2006.

Karge, Heike. Sećanje u kamenu - okamenjeno sećanje? Trans. Aleksandra Kostić. Belgrade: XX vek, 2014

Kertzer, David I. Ritual, Politics, Power. New Haven: Yale University Press, 1998.

Kirn, Gal . "A Few Critical Notes on the Destiny of the Yugoslav Partisan Memorial Sites in the Contemporary, Post-Yugoslav (Croatian) Context," in Nataša Ivančević, ed., Vojin Bakić: Lightbearing Forms - A Retrospective. Zagreb: Muzej suvremene umjetnosti, 2013.

Kirn, Gal and Burghardt, Robert. "Jugoslovenski partizanski spomenici: Između revolucionarne politike i apstraktnog modernizma," in Jugolink, 2,1 (2012).

Lakoff, George. Moral Politics: What Conservatives Know that Liberals Don't. Chicago, Ill.: University of Chicago Press, 1996.

Lakoff, George. The Political Mind: A Cognitive Scientist's Guide to Your Brain and Its Politics. New York: Penguin Books, 2009.

Lončar, Duško. Deset godina spomen-područja Jasenovac. Jasenovac: Spomen-područje Jasenovac, 1977 .

Mataušić, Nataša. 2003. Jasenovac 1941-1945. Zagreb: Kameni cvijet.

Mataušić, Nataša. 2006. “The Jasenovac Concentration Camp," in Tea Benčić Rimay, ed. Jasenovac Memorial Site. Jasenovac: Spomen-područje Jasenovac.

Pavlaković, Vjeran. 2010. "Deifying the Defeated: Commemorating Bleiburg since 1990," in L'Europe en Formation, No. 357.

Pavlaković, Vjeran. "Contested Pasts, Contested Red-Letter Days: Antifascist Commemorations and Ethnic Identities in Post-Communist Croatia," in Ljiljana Šarić, Karen Gammelgaard, and Kjetil Ra Hauge, eds., Transforming National Holidays: Identity Discourse in the West and South Slavic Countries, 1985-2010. London: John Benjamins Publishing, 2012.

Pavlaković, Vjeran. "Symbols and the culture of memory in the Republika Srpska Krajina," in Nationalities Papers, 41, 6 (2013).

Pavlaković, Vjeran. "Fulfilling the Thousand-Year-Old Dream: Strategies of Symbolic Nation-building in Croatia”, in Pål Kolstø, ed., Strategies of Symbolic Nation-building in South Eastern Europe. Farnham: Ashgate, 2014.

Pavlowitch, Stevan K. Hitler's New Disorder: The Second World War in Yugoslavia. London: Hurst \& Company, 2008.

Perak, Benedikt, Puljar D’Alessio, Sanja. “Kultura kao emergentno svojstvo otjelovljene spoznaje”, in Fanuko, Nenad i Puljar D’Alessio, Sanja (eds.) Avanture kulture: kulturalni studiji u lokalnom kontekstu. 77-108. Zagreb: Jesenski i Turk, 2013.

Radvansky, Gabriel A. and Zacks, Jeffrey M. Event Cognition. Oxford: Oxford University Press, 2014. 
Radonić, Ljiljana. "Univerzalizacija holokausta na primjeru hrvatske politike prošlosti i spomen-područja Jasenovac," in Suvremene teme, 3,1 (2010).

Ramet, Sabrina P., ed. The Independent State of Croatia, 1941-45. London: Routledge, 2007.

Rimay, Tea Benčić, ed. Jasenovac Memorial Site. Jasenovac: Spomen-područje Jasenovac, 2006.

Scherer, Klaus. "Emotions are emergent processes: they require a dynamic computational architecture" in Philosophical Transaction of the Royal Society, 364 (2009): 3459-3474.

Sharifian, Farzad. "Cultural linguistics", in Farzad Sharifian, ed., The Routledge Handbook of Language and Culture. 473-492. London: Routledge, 2015.

Svob, Connie, Brown, Norman R., Takšić, Vladimir, Katulić, Katarina and V. Žauhar. “Intergenerational Transmission of Historical Memories and Social-Distance Attitudes in Post-War Second-Generation Croatians", in Memory \& Cognition 2016.

Tomasevich, Jozo. War and Revolution in Yugoslavia, 1941-1945: Occupation and Collaboration. Stanford: Stanford University Press, 2001.

Tuđman, Franjo. Bespuća povijesne zbiljnosti: Rasprava o povijesti i filozofiji zlosilja. Zagreb: Nakladni zavod Matice Hrvatske, 1990.

Tuđman, Franjo. “The Sources, Changes, and Essence of the National Question in the Socialist Federal Republic of Yugoslavia," reprinted in Peter Sugar, ed. Eastern European Nationalism in the Twentieth Century. Washington, DC: American University Press, 1995.

Žerjavić, Vladimir. Opsesije i megalomanije oko Jasenovca i Bleiburga. Zagreb: Globus, 1992. 